\title{
How embryos work: a comparative view of diverse modes of cell fate
} specification

\author{
ERIC H. DAVIDSON \\ Division of Biology, California Institute of Technology, Pasadena, CA 91125 USA
}

\begin{abstract}
Summary
Embryonic processes in the nematode $C$. elegans, the gastropod mollusc Ilyanassa, the dipteran Drosophila, the echinoid Strongylocentrotus purpuratus, the ascidian Ciona, the anuran Xenopus, the teleost Brachydanio and mouse are compared with respect to a series of parameters such as invariant or variable cleavage, the means by which the embryonic axes are set up, egg anisotropies and reliance on conditional or on autonomous specification processes. A molecular interpretation of these modes of specification of cell fate in the embryo is proposed, in terms of spatial modifications of gene regulatory factors. On this basis, classically defined phenomena such as regulative development and cytoplasmic localization can be interpreted at a mechanistic level, and the enormous differences between different forms of embryogenesis in the Animal Kingdom can be considered within a common mechanistic framework. Differential spatial expression of histospecific genes is
\end{abstract}

considered in terms of the structure of the gene regulatory network that will be required in embryos that utilize cell-cell interaction, autonomous vs conditional specification and maternal spatial information to differing extents. It is concluded that the regulatory architectures according to which the programs of gene expression are organized are special to each form of development, and that common regulatory principles are to be found only at lower levels, such as those at which the control regions of histospecific structural genes operate.

Key words: variable cleavage, invariant cleavage, axis determination, cell fate, conditional specification, autonomous specification, gene regulation, regulative development, cytoplasmic localization, cell-cell interaction, gene expression, maternal role, C. elegans, Drosophila, Strongylocentrotus purpuratus, Ciona, Xenopus, Brachydanio, mouse.

\section{Introduction}

The initial objective of the embryonic developmental mechanism is to impose the correct spatial patterns of differential gene expression in the nuclei that populate the egg cytoplasm during cleavage. The term specification of cell fate is used in this article, as previously (Davidson, 1986, p. 195; Davidson, 1989), to denote the process(es) by which the differentiated fates of the progeny of cleavage stage blastomeres are first established in the undisturbed embryo (whether irreversibly or not is here unimportant). Expression of diverse cell fates during embryogenesis clearly requires differential gene transcription. Thus the result of specification is to produce, in the initially naive and equivalent cleavage stage genomes, a mosaic of gene activity patterns, defined for each nucleus with reference to its position in the embryo. So much seems simple, obvious and general, and also fundamental. At least in an abstract sense, the subsequent processes of development all follow from the initial appearance of specialized cell lineages formulated as a result of the initial rounds of cell fate specification, whenever in development that first occurs. Classical authors, however, and those of their successors who have attempted to deal with more than one embryonic form, have been struck by the amazing variety in the modes of embryonic development that exist in the various phylogenetic reaches of the Animal Kingdom. It has been obvious for many years that in itself the simple concept 'imposition of spatial patterns of differential gene expression' does not provide the student of comparative aspects of early development with any very useful keys to interpretation of the specific biological phenomenology of each form of embryogenesis. All embryos do indeed achieve the imposition of spatial patterns of differential gene expression, and yet some begin this process by intercellular interaction, and others even before there are any cells that could carry out such interactions; some rely on lineages that are autonomously committed to given functions from the moment they appear, others deal wholly in plastic, malleable cell fate assignments; some utilize eggs that before fertilization are cytoskeletally organized in both axes, some in one axis only, some apparently in neither; for some kinds of embryos every individual has a different cell lineage, while for others development depends on a set of rigidly reproducible canonical cell lineages; and some embryos display truly 
amazing regulative capacities. It is the last - the ability to functionally reorganize parts of larvae, and sometimes to generate complete larvae anew from parts or artificial fusions of parts - that serves to focus our basic difficulty in understanding the mechanisms of embryonic development. Regulative embryonic processes require that cell specification may occur differently under different conditions in the same species of embryo. But why can some embryos (and some parts of embryos) regulate and others not? These are the kinds of deep phenomenological problems that a century of often brilliant classic and neoclassic experimental developmental biology has left with us. For the differences among taxa in their modes of embryonic development are anything but trivial and superficial (certain hopeful reductionist delusions of recent years to the contrary). The objectives of this article are, first, to formalize a set of biological characteristics that usefully classify different forms of early embryonic development, and, second, to propose in outline a general interpretation of the definitive process of cell fate specification. It is then possible to approach a regulatory analysis of various phenomena of early development in diverse creatures, and thus to consider the various means by which are generated the spatial patterns of gene expression that in all forms underlie embryonic differentiation.

\section{Comparison of diverse embryonlc processes}

\section{Some useful classificatory features}

What are the important features of embryogenesis that distinguish different animal groups, and what is their significance? The answer to the first of these questions of course depends on the nature of the answer to the second that one has in mind. Here we take the view that the significant features are those that have to do directly or indirectly with the distribution in embryonic space of gene regulatory molecules. Working backwards, if a given set of cells differentially expresses a certain set of genes early in development, then the important features to identify are those relevant to the initial appearance of positively acting gene regulatory factors in these cells or in their lineage ancestors, or of negatively acting factors in other cells or their ancestors.

In Table 1 , a range of enormously diverse embryonic forms is parsed, in terms of a few basic features of their development, for which a molecular level interpretation is offered below. Table 1 considers the development of representative animals of eight different taxa for which there is considerable information available. It is evident at a glance that these organisms utilize profoundly different strategies to achieve development. The top row of Table 1 , which is devoted to $C$. elegans, represents a pseudocoel grade of organization (mesodermal lining only on inner body wall), while all the rest are true coelomate animals (mesodermal linings both on body wall and in and around viscera). The next two rows of Table 1 , representing advanced molluscan and insect forms, are protostomial animals; and the last five are deuterostomial animals. These are an echinoderm, representing the stem themes of lower deuterostome evolution (Jefferies, 1986); an ascidian; and three true vertebrates. Columns 2, 3 and 4 of Table 1 include elemental classificatory parameters of embryogenesis in these organisms (and by extension in the taxonomic groups to which they belong); and columns 5, 6 and 7 list some further useful classifications, but also include in very abbreviated form a variety of specific descriptive information, to which we shall have occasion to refer in the following.

Columns 2 and 4 of Table 1 directly imply various forms of maternal spatial organization, or anisotropies, in the molecular structure or the cytoarchitecture of the egg. Column 2 concerns a basic feature of cleavage in each form, with respect to subsequent development. An invariant cleavage pattern requires that in all embryos of the species the cleavage planes throughout are in the same positions, producing an identifiable, canonical, three-dimensional array of blastomeres. In undisturbed embryos displaying invariant cleavage, the fates of the progeny of each cell in the canonical cleavage pattern are therefore also invariant and are entirely predictable. Certain cleavage planes will serve as interfaces between lineages or lineage founder cells that display diverse fates. Since these fates depend on subsequent differential gene expression, it follows that the invariant cleavage planes divide up the embryo into a set of spatial domains, each defined by a specific set of subsequent gene regulatory properties. Consequently, the invariant cleavage geometry is an essential parameter of cell fate specification. In other words, invariant cleavage potentiates precise spatial regulatory mechanisms that are not available as such to organisms in which the differentiated parts of every individual have a different lineage (variable cleavage), or in which spatial specification of cell fate is initiated or completed before there are any cell boundaries (syncytial cleavage). Specification in variably cleaving eggs, for example, as in amphibian embryos, may still rely on inheritance by blastomeres of special regions of egg cytoplasm, irrespective of cell lineage. In fact, however, the most important mechanism of cell specification in variably cleaving eggs (as also in some invariantly cleaving embryos) appears to be positional specification mediated by diffusible ligands or ligands mounted on adjacent cells. Ligands, as used here, refers to intercellular signalling molecules bound specifically by membrane receptors, thereby setting in train an intracellular signal transduction event. This whole class of embryonic specification process is in turn inapplicable to syncytially cleaving eggs in which differential genomic function is established prior to the point when there appear the membrane-enclosed cytoplasmic domains that are required for specification by intercellular signalling. These arguments show, in a very general way, how the forms of cleavage mandate, or restrict, possible mechanisms of spatial regulation right from the start.

Since the positions occupied by given lineage founder cells are of paramount importance in embryos that rely on invariant, canonical cleavage patterns, it would not 
Table 1. Parameters of diverse forms of embryogenesis ${ }^{\mathrm{a}}$

\begin{tabular}{|c|c|c|c|c|c|c|}
\hline \multirow[b]{2}{*}{$\begin{array}{l}\text { Animal: } \\
\text { exemplary } \\
\text { genus } \\
\text { (group) }\end{array}$} & \multirow[b]{2}{*}{$\begin{array}{l}\text { Cleavage } \\
\text { pattern }\end{array}$} & \multirow[b]{2}{*}{$\underset{\text { migration }}{\text { Cell }}$} & \multirow[b]{2}{*}{$\begin{array}{c}\text { Axial egg } \\
\text { anisotropy } \\
\text { established in } \\
\text { oogenesis }^{c}\end{array}$} & \multirow{2}{*}{$\begin{array}{c}5 \\
\text { Formation of } \\
\text { second axis: } \\
\text { postfertilization } \\
\text { process }\end{array}$} & \multicolumn{2}{|c|}{${ }^{6}{ }^{7}{ }^{d}$} \\
\hline & & & & & $\begin{array}{l}\text { Autonomously } \\
\text { specified } \\
\text { cell lineages }\end{array}$ & $\begin{array}{l}\text { Conditionally } \\
\text { specified } \\
\text { cell lineages }\end{array}$ \\
\hline $\begin{array}{l}\text { C. elegans" } \\
\text { (nematode) }\end{array}$ & invariant & very little & $\mathrm{A} / \mathrm{P}$ axis? & $\begin{array}{l}\text { cytoplasmic } \\
\text { polarization? } \\
\text { (D/V axis) }\end{array}$ & $\begin{array}{l}\text { gut; germ line; } \\
\text { posterior body } \\
\text { muscles }\end{array}$ & $\begin{array}{l}\text { pharyngeal muscles; } \\
\text { pertaps most } \\
\text { anterior lineages }\end{array}$ \\
\hline $\begin{array}{l}\text { Ilyanassa } \\
\text { (gastropod } \\
\text { mollusc) }\end{array}$ & invariant & very little & An/Vg axis & $\begin{array}{l}\text { relative positions } \\
\text { of 1st cleavage } \\
\text { plane and junction } \\
\text { of polar lobe } \\
\text { (D/V axis) }\end{array}$ & $\begin{array}{l}\text { axial mesodermal } \\
\text { primordium; } \\
\text { gut; heart }\end{array}$ & $\begin{array}{l}\text { eye; foot; } \\
\text { shell gland }\end{array}$ \\
\hline $\begin{array}{l}\text { Drosophila } \\
\quad \text { (dipteran insect) }\end{array}$ & $\begin{array}{l}\text { syncytial } \\
\text { \& variable }\end{array}$ & very little & $\begin{array}{l}\mathrm{A} / \mathrm{P} \text { and } \\
\mathrm{D} / \mathrm{V} \text { axes }\end{array}$ & see column 4 & $\begin{array}{l}\text { pole cells (major } \\
\text { A/P \& D/V } \\
\text { pattern elements } \\
\text { spectied } \\
\text { regionally } \\
\text { before } \\
\text { cellularization) }\end{array}$ & $\begin{array}{l}\text { neuroblasts in } \\
\text { neurogenic } \\
\text { ectoderm; } \\
\text { some } \\
\text { cuticular } \\
\text { structures; } \\
\text { dorso-ventral } \\
\text { ectodermal } \\
\text { cell types }\end{array}$ \\
\hline $\begin{array}{l}\text { Stronglyocentrotus } \\
\text { (echinoderm) }\end{array}$ & invariant & $\begin{array}{l}\text { skele togenic } \\
\text { and } 2^{\circ} \\
\text { mesenchyme } \\
\text { only }\end{array}$ & $\mathrm{An} / \mathrm{V}_{\mathrm{g}}$ axis & $\begin{array}{l}\text { cytoplasmic } \\
\text { polarization } \\
\text { relative to } \\
\text { 1st cleavage } \\
\text { plane } \\
\text { (O/Abo axis) }\end{array}$ & $\begin{array}{l}\text { skeletogenic } \\
\text { mesenchyme }\end{array}$ & $\begin{array}{l}\text { gut; O ectoderm; } \\
\text { Abo ectoderm }\end{array}$ \\
\hline $\begin{array}{l}\text { Ciona } \\
\quad \text { (ascidian) }\end{array}$ & invariant & very little & $\begin{array}{l}\mathrm{An} / \mathrm{V}_{\mathrm{g}} \text { axis } \\
\quad=\mathrm{D} / \mathrm{V} \text { axis }\end{array}$ & $\begin{array}{l}\text { cytoplasmic } \\
\text { polarization, } \\
\text { relative to of } \\
\text { pn migration with } \\
\text { cortical } \\
\text { contraction } \\
\text { (A/P axis) }\end{array}$ & $\begin{array}{l}\text { muscle; gut; } \\
\text { notochord; } \\
\text { epidermis }\end{array}$ & $\begin{array}{l}\text { caudal tip } \\
\text { muscles; } \\
\text { brain; } \\
\text { melanocytes; } \\
\text { palps }\end{array}$ \\
\hline $\begin{array}{l}\text { Xenopus' } \\
\text { (anuran } \\
\text { amphibian) }\end{array}$ & variable & $\begin{array}{l}\text { limited } \\
\text { prior to } \\
\text { initial } \\
\text { specifications: } \\
\text { later } \\
\text { extensive }\end{array}$ & $\mathrm{An} / \mathrm{Vg}$ axis & $\begin{array}{l}\text { cortical rotations } \\
\text { relatuve to } \\
\text { sperm entry } \\
\text { point (or } \\
\text { gravity) } \\
\text { (D/V axis) }\end{array}$ & $\begin{array}{l}\text { gut endoderm; } \\
\text { ciliated } \\
\text { ectoderm }\end{array}$ & $\begin{array}{l}\text { axial and ventral } \\
\text { mesoderm; } \\
\text { neuroblasts; } \\
\text { brain }\end{array}$ \\
\hline $\begin{array}{l}\text { Brachydanio } \\
\text { (teleost fish) }\end{array}$ & variable & extensive & $\mathrm{An} / \mathrm{V}_{\mathrm{g}}$ axis & unknown & none known & $\begin{array}{l}\text { axial and } \\
\text { ventral mesoderm; } \\
\text { neuroblasts; } \\
\text { peripheral } \\
\text { and CNS; } \\
\text { notochord; } \\
\text { pigment cells }\end{array}$ \\
\hline $\begin{array}{l}\text { Mus } \\
\text { (mammal) }\end{array}$ & variable & extensive & none & unknown & none known & $\begin{array}{l}\text { all lineages of } \\
\text { the definitive } \\
\text { embryo }\end{array}$ \\
\hline
\end{tabular}

"Except where additional references are indicated, and except for general knowledge easily available in embryology texts, data for this Table (and the major original references) are to be found in Chapters 4 and 6 of Gene Activity in Early Development, Davidson (1986).

${ }^{b}$ Not including mutual changes in the positions of contiguous cells occurring during archenteron invagination. Refers only to migration during formation of the embryo, as opposed to postembryonic migratory processes that occur in all species.

'Abbrevations: $\mathrm{D} / \mathrm{V}$, dorsal-ventral; $\mathrm{An} / \mathrm{V}_{\mathrm{g}}$, animal-vegetal; $\mathrm{A} / \mathrm{P}$, anterior-postenor; $\mathrm{O} / \mathrm{Abo}$, oral-aboral. These primordial axes are all probably irreversible and play a role in organizing the spatial structure of the embryo.

Thesc entrics denote the presumed lineages that contribute essentially to the postgastrular structures listed, and not necessarily (though most probably) all of the lineages required for the morphogenesis of the listed structure or structures. Only cell types of the embryo per se, not precursors of extraembryonic membranes are considered. See text for references.

- Sec, c.g., Strome and Wood (1982); Albertson (1984); Strome, 1989; Priess and Thomson (1987). The latter showed that exchange of position of certain early blastomeres causes reversal of $\mathrm{D} / \mathrm{V}$ polarity, and this is clearly the labile axis. The $\mathrm{A} / \mathrm{P}$ axis 13 probably primordial; at least the polar bodies appear at the future anterior end (Strome, 1989). The polar granules migrate to the posterior end, completing the cytological organization of the egg in this axis, just before cleavage (Strome and Wood, 1982).

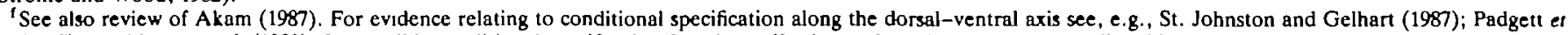
al. (1987); Hashimoto et al. (1988); for possible conditional specification functions affecting early cuticular pattern, mediated by segment polarity genes, see, e.g., Cabrera et al. (1987); Martinez-Arias et al. (1988). Direct observations of plasticity in cell fate, which is evidently determined by identity of neighboring cells, has been obtained in blastomere transplantation experiments carried out with epidermal, neurogenic and mesodermal precursors by Technau and Campos-Ortega (1986); Beer et al. (1987); Technau el al. (1988).

See also review of Davidson (1989).

${ }^{\mathrm{h}}$ See also Nishida (1987); Nishikata et al. (1987a,b); Reverberi et al. (1960); Ortolani (1987).

'See also Gurdon (1987, 1989); Vincent and Gerhart (1987); Danilchik and Gerhart (1987). The autonomous specification of endodermal and ectodermal cell types is indicated by studies of ectodermal and endodermal marker expression in isolated blastomeres (Jones and Woodland (1986); Sargent et al. (1986), and for endodermal cell types, by the uniform fates of labeled vegetal blastomeres in undisturbed eggs (see text). However, in both cases, the fates of these cell types can be altered if they are placed in ectopic contexts (Sargent et al. 1986; Wylie et al. 1987; Snape et al. 1987), and these assignments are certainly in the category of 'possible examples'.

${ }^{j} \mathrm{Sec}$ Kimmel and Law $(1985 a-c)$; Kimmel and Warga $(1986,1990)$; Kimmel et al. (1990). In this embryo, histospecific lineages arise after gastrulation is complete. See also Ballard (1973). 
be expected that large-scale cell migrations would occur until after specification. Nor would extensive migrations be expected before the various states of differentiation expressed by early lineages have become irreversible, which is what in this article is denoted by the term commitment. Thus, as column 3 of Table 1 shows, all the embryos in which cleavage is invariant in fact display little precocious cell migration (the early migration of sea urchin skeletogenic mesenchyme cells follows an even earlier lineage commitment). In contrast, a notable feature of some vertebrate forms displaying variable cleavage is the enormous clouds, or sheets, of yet unspecified, pluripotential cells that migrate over or within the embryo prior to lineage diversification. The ultimate specification of these cells in general depends at least in part on their eventual relocation during gastrulation.

\section{Axial anisotropies of the egg and cytoplasmic localization}

Column 4 of Table 1 categorizes the various forms according to the embryonic axes that are prespecified in their eggs. This is a key index of primordial anisotropy, i.e. a developmentally significant organizational feature imposed on the structure of the egg during oogenesis. It might be inferred that an invariant cleavage pattern would require such a preorganization of the egg, in at least one axis. However, some examples studied by Freeman (1977) are inconsistent with this argument. This work demonstrates an invariant, canonical cleavage pattern in the eggs of three species of ctenophore, but there is no preformed axial egg organization in these eggs. Their initial (oral-aboral) axis is determined by the plane of first cleavage, but this may lie in any orientation with respect to the polar bodies (Freeman, 1979). However, all the eggs included in Table 1, except the mouse egg, are in fact primordially polarized along at least one axis in a way that affects the organization of the embryo, and this is true of the variably cleaving as well as of all the invariantly cleaving eggs listed. The axial anisotropy represented by the primordially established axis provides spatial references for the organization of the embryo as development begins. Thus, for example, in all the eggs included in Table 1 (except the Drosophila egg, where cleavage is syncytial, and the mouse egg, where there is no primordial axis), the plane of first cleavage is established with reference to the primordial axis of the egg. That is, this plane is orthogonal to the primordial anterior-posterior axis in the $C$. elegans egg, and it lies in the primordial axis in the other forms. However, there is in many cases a more general and fundamental significance to axial egg anisotropy. This is that the primordial axis is used, by various mechanisms, to specify future cell fates, at least at one pole of the egg.

The concept of 'cytoplasmic localization of morphogenetic potential' in eggs can be regarded as one of the major insights of classical embryological thought. Localization in this sense may be defined as the specification of cell fate according to the section of egg cytoplasm inherited by an embryonic cell lineage or lineages (see reviews of Wilson, 1896, 1925). Modern developmental biologists, particularly those working with molluscan, nematode, insect, ascidian and echinoderm embryos, have succeeded in providing powerful and detailed experimental evidence for localization (reviewed by Davidson, 1986; Chapter 6). The localization phenomenon, where the term properly applies, requires that there exist maternal cytoplasmic elements that are spatially sequestered by the time cleavage is underway, and that the sequestration of these maternal cytoplasmic elements by given embryonic blastomeres is sufficient to determine their state of specification. This can be established, for example, by experimental demonstration that when the relevant region of egg cytoplasm is in some way shunted to other cells, these now assume the fate that would have been imposed on the original inheritors of this cytoplasm (see review op. cit.). Localized maternal elements that phenomenologically appear to function in this way are often aligned along the primordial axes of the egg. Thus, for example, the Drosophila egg possesses pole cell determinants that can be functionally assayed after microinjection into ectopic regions of other embryos (Illmensee and Mahowald, 1974, 1976); and also prelocalized anteriorposterior and dorsal-ventral cytoplasmic maternal determinants (see, e.g., reviews of Akam, 1987; Nüsslein-Volhard et al. 1987; Anderson and Nüsslein-Volhard, 1984; Levine, 1988; Rushlow et al. 1989). Similarly, the sea urchin egg probably possesses determinants for the skeletogenic specification of micromere lineages arising at the vegetal end of the primordial animal-vegetal axis (reviewed by Davidson, 1989).

In many of the clearest experimentally demonstrated examples of localization, however, the determinative cytoplasmic elements are positioned at one pole of the second axis of the egg, which is not primordial, but is spatially defined after fertilization or in the course of the train of events initiated by fertilization. As shown in column 5 of Table 1, the phenomenology of second axis specification is indeed various. In some eggs, this axis is established with respect to the plane of first cleavage, e.g. in Strongylocentrotus (Cameron et al. 1989) or Ilyanassa (reviewed by Davidson, 1986, pp. 453-467); in some eggs vice versa, as in Ciona (Conklin, 1905; Jeffery, 1982; Bates and Jeffery, 1988); or, independently of it, as in Xenopus (Black and Vincent, 1988; Danilchik and Black, 1988) or Brachydanio (Kimmel and Law, 1985a). The only generalization that can be made for most of the cases listed in column 5 is that an asymmetry in the plane orthogonal to the primordial axis is converted into a cytoplasmic movement or cytoskeletal polarization in the plane of the future second axis. However, in the teleost and mammalian embryos, the second axis probably is not established until many cells have arisen. Though the process is unknown in these eggs, in the chick embryo the anterior-posterior axis is specified gravitationally late in cleavage as cells accumulate at the lowest end of the blastocoel, which becomes the head, and until then the blastodisc is radially equipotential (Clavert, 1960a,b; 
Eyal-Giladi, 1969). The initial source of asymmetry in other forms where the axes are set up by first cleavage may be the point of sperm entry (Xenopus), or the direction of migration of the male pronucleus (Ciona), or some other disturbance of the radial architectural equivalence of the egg that is occasioned by fertilization. While these natural stimuli suffice, they are often not necessary. Second axis formation is initially an extremely labile phenomenon, easily overridden by introducing new sources of asymmetry, e.g., gravitational force in Xenopus eggs (Gerhart et al. 1983; Scharf and Gerhart, 1983), or local application of a $\mathrm{Ca}^{2+}$ ionophore in Ciona eggs (Bates and Jeffery, 1988). Examples of spatial localization after fertilization of maternal cytoplasmic elements that appear to affect cell specification along the second axis include localization of muscle determinants at the posterior pole of the ascidian egg; of mesodermal and gut determinants at the dorsal pole of the llyanssa egg; and of comb plate and photocyte determinants in ctenophore eggs (these cases are reviewed by Davidson, 1986; Chapter 6).

\section{Localization and autonomous specification of cell lineages}

From the strong form of the definition of localization given above, it follows that cell lineages established by inheritance of regionally sequestered maternal factors should be specified autonomously. That is, the processes by which are established the identity of the lineages, and the ultimate patterns of differentiation in the cells of these lineages, should not depend qualitatively on contact with other cell types or signals emanating from other cell types. If the maternal cytoplasmic elements are indeed sufficient for specification, the founder cells inheriting them should differentiate in the same histospecific direction whether or not the cells are placed in ectopic positions in the embryo, in culture (assuming the conditions are adequate), or with or without contact with other cell types. The term histospecific is used here to refer to particular differentiated cell types. Furthermore, since the cells of such lineages have no need to be responsive to signals from other cell types, there is no reason to expect them to display plasticity in their state of specification; they will not participate in regulative respecification; and they should belong to the cohort of earliest functionally differentiated cell types to appear. For these cell lineages there might be no temporal distinction between specification and commitment, since their signals come from within, so that they do not require a long period of 'competence' during which they can make a variety of responsive choices. It is easy to imagine that these corollaries are too harsh and exclusive, since there could be cell types that are specified by a combination of bona fide localized maternal factors and intracellular interactions, and that would retain some plasticity and would behave differently depending on their contacts with other cells. Thus it is interesting and significant that embryonic cell lineages that display the autonomous properties predicted by the strong form of the localization theory do indeed appear to exist in many different forms of embryo. A number of probable or possible examples are given in column 6 of Table 1 . The polar axial locations at which arise many of these cell lineages was remarked on above. The implication is that localization of the determinants by which they are specified is to be explained by their physical association with the cytoskeletal structures that establish the biaxial organization of the early embryo.

\section{Conditional specification of cell fate and regulative capacity}

In column 7 of Table 1 are to be found a number of examples of specific lineages, or at least types of progenitor cell (see note d), that in our archetypical embryonic forms seem clearly to be specified by intercellular interaction. The state of specification of these cells depends explicitly on their extracellular context, and is not an intrinsic property. Such cells or cell lineages are therefore to be thought of as conditionally specified. Table 1 shows that while none of our embryos rely wholly on autonomously specified lineages (as in column 6) some, e.g. the mouse and zebrafish embryos, probably operate entirely by conditional specification. In fact, taking columns 6 and 7 together, most of the embryos included seem to utilize both conditional and autonomous specification. In these 'mixed forms', early cytoplasmic anisotropies, either those organized primordially or soon after fertilization, are utilized for the specification of one or a few autonomous polar lineages, and to establish the embryonic axes. The remainder of the embryo, usually most of it, is specified conditionally by means of cell interactions. An implication is that the autonomously specified elements of the embryo might initially serve as the source of ligands specifying adjacent or nearby cells, to provide a spatial starting point, so to speak. In the sea urchin embryo and in anuran embryos, there is good evidence that this is the case, as discussed in later sections. Ascidian embryos present a quantitative exception, as a larger fraction (though certainly not all) of the early lineages in these embryos appear to differentiate autonomously than in the other forms; and relatively large portions of at least the posterior half of the $C$. elegans embryo may also be autonomously specified (Table 1).

It is important to note that primordial or secondary axial anisotropies in the egg cytoarchitecture are used to set up systems of cellular interaction as well as to set up systems of autonomous specification. Thus, for example, specification of the blastomeres at the animal pole end of the $\mathrm{An} / \mathrm{Vg}$ axis of the sea urchin egg is entirely conditional, dependent on signals from adjacent cells, while at the vegetal pole of the same axis there arises the autonomous skeletogenic mesenchyme lineage. Many of the other embryos included in Table 1 provide similar examples. In Xenopus eggs, establishment of the dorsal-ventral axis sets up a polarized induction system (reviewed by Smith and Slack, 1983; Smith, 1989) and there is no evidence for any autonomously specified cell type along this axis, at least of the robust quality of specification characteristic of the autonomous examples discussed above.

It remains useful to reexamine the classical argument 
that 'embryos are mosaic or regulative'. This is of course a misstatement when applied to embryos as a whole, since as we have seen there is no example that is constructed wholly of autonomously specified cell lineages, as required by the moniker 'mosaic embryo'. However, it is not an unreasonable distinction when applied to parts of embryos, i.e. embryonic cell lineages or sets of lineages. Perhaps the most important corollary of the concept of conditional specification advanced here is that conditional specification implies regulative capabilities. That is, since the recipient cells are plastic and depend on external signals for specification, they must necessarily possess a greater qualitative range of differentiation capacities than they manifest in the undisturbed embryo. When some of these capacities are elicited, as in an ectopic blastomere recombination, or an embryo fusion experiment, the results provide examples of regulative development. Because conditional specification is so generally a feature of embryogenesis (Table 1); and because second axis formation itself often begins with an unstable and easily perturbed cytoarchitectural reorganization, the ability to generate regulative developmental behavior is very widespread. Indeed, considered as a consequence of conditional specification, regulative competence is to be predicted as a general property of many embryonic elements. Conditional specification also obviously implies that specification precedes commitment, and that competence to respond to external signals is spatially more widespread and temporally longer in duration than minimally required. But these characteristics, which follow from the plasticity inherent in embryonic cells that are to undergo conditional specification, are applicable only within clear and predictable limits, viz. those set by the autonomous features and cell lineages described in columns 4 and 6 of Table 1 . The grain of truth that is embodied in the old regulative-mosaic dichotomy is thus that there are indeed two robust clusters of phenomenological properties: plasticity, delayed commitment and regulative behavior all imply normal processes of conditional specification; while rigidity, early commitment and lack of regulative competence all imply forms of autonomous specification by cytoplasmic localization.

\section{Molecular interpretation}

Molecular regulatory mechanisms that may underlie the biological processes of conditional and autonomous specification in embryos are considered from a general point of view in this section. Such mechanisms provide an approach to the interpretation of some of the embryonic specializations to be found in Table 1 , and for several of the phenomenological parameters serving there as column headings.

\section{Autonomous specification}

A rather obvious interpretation of localization and autonomous specification, in terms of maternal gene regulatory factors, has now been with us for more than
20 years (Davidson et al. 1965; Davidson, 1968; Davidson and Britten, 1971), though it yet remains essentially undemonstrated. The morphogenetic agents of classical writers, which are localized in certain regions of the egg cytoplasm, were proposed in these arguments to be positively acting regulatory transcription factors that control histospecific batteries of genes. When the element of egg cytoplasm in which these factors would be sequestered is inherited by given blastomeres, the lineages to which these blastomeres give rise would thereby be committed to differentiate. Consider the Ilyanassa polar lobe cytoplasm, for example, which endows the macromere inheriting it with the capacity to give rise to the axial mesoderm founder cells ( $\mathbf{M} \mathbf{E}_{1}$ and $\left.\mathbf{M E}_{2}\right)$ and the entoblasts or gut founder cells $\left(\mathbf{E}_{\mathbf{1}}\right.$ and $\left.\mathbf{E}_{2}\right)$ (Clement, 1952; 1962; reviewed by Davidson, 1986, pp. 453-461). As initially suggested for this case (Davidson et al. 1965), this cytoplasm, in current terms, would contain maternally synthesized regulatory proteins (or their mRNAs) that will activate the specific programs of gene activity required by these founder cells and their immediate progeny. Similarly, regulatory factors (or their mRNAs) controlling muscle gene batteries should be localized in ascidian egg 'myoplasm,' since inclusion of this cytoplasm appears to cause muscle lineage differentiation, both in normal and experimentally altered cleavage (Whittaker, 1980, 1982; Deno and Satoh, 1984). Thus it might be predicted that something like myoD, or one of its cousins (Tapscott et al. 1988; Wright et al. 1989; Braun et al. 1989; Weintraub et al. 1989; Pinney et al. 1988), or an upstream regulator of the genes producing such factors, would be associated with the myoplasm that is sequestered in the autonomous muscle founder cells (i.e. the B4.1 cells). Or that, in the C. elegans egg, regulators controlling the gut gene battery of which esterase is a known element should be sequestered in the autonomous gut lineage founder cell (the $\mathbf{E}$ blastomere; Sulston et al. 1983); etc. One advantage of this theory in this, shall we say, its most extreme and uncomplicated form, is the directly testable, straightforward predictions it engenders, as suggested in the cartoon shown in Fig. 1. However, it is not a unique solution to the problem, even in principle. For example, it could be that the regulators in question are in fact globally distributed in the egg, but in a form that is not functional, and that an enzymatic apparatus, e.g. a kinase, that can make them functional is what is actually sequestered in the relevant elements of egg cytoplasm. Or, as Rushlow et al. (1989) have shown for dorsoventral specification in Drosophila, a protease could be localized that by clipping a 'pre-regulatory factor' causes it to be regionally translocated into the nucleus. In this case, the 'pre-factor' is the product of the dorsal gene, which is a gene regulatory factor required for ventral differentiation, that is present in the cytoplasm both dorsally and ventrally, but which is processed and accumulated in the nuclei only on the ventral side. A third possibility is that what is apparently autonomous specification actually operates by an autocrine mechanism; that is, what is sequestered is a ligand, (or its mRNA) for which the blastomeres also 
contain a receptor $a b$ initio. The cells would thus stimulate themselves, and would utilize a signal transduction mechanism to generate their own active histospecific regulators. An idea of this kind was proposed by Rosa (1989) for the endoderm precursor cells of Xenopus. A feature of an autocrine mechanism is that the cells of such a lineage should be responsive to ligands emitted from one another as well as from themselves, and therefore these cells should differentiate better, more, or perhaps only, when they are in contact or in proximity. Such a mechanism could be utilized to promote identical specification in a cluster of contiguous cells ('community effect'; Gurdon, 1989). While this cannot be excluded for Xenopus endoderm (since we lack molecular markers for endoderm differentiation), an autocrine mechanism would be most unlikely for examples such as the sea urchin embryo lineages forming skeletogenic mesenchyme, or the ascidian lineages forming muscle. In both these cases, the lineage founder cells can be isolated from wholly dissociated embryos and cultured at very high dilution (compared to their situation in the embryo), and yet they differentiate in vitro, or express histospecific molecular markers, essentially as in vivo (reviewed by Davidson, 1986, pp. 220-229, 420-436; Nishikata et al. $1987 a$ ). Another related mechanism is exemplified by the disposition of torso gene products in Drosophila. Torso codes for a maternal receptor-like protein with affinities to the PDGF-tyrosine kinase group of mammalian receptors (Sprenger et al. 1989). The protein is uniformly distributed in the egg (Klingler et al. 1988), though torso function is required only for the terminal regions. A likely explanation for the localization of torso function is that a ligand originating from surrounding cells of the follicle at the anterior and posterior ends of the oocyte binds to the torso receptor in these regions during oogenesis, and remains there stably throughout early development (Sprenger et al. 1989; Casanova and Struhl, 1990). This would be a receptor-mediated system that nonetheless behaves autonomously after fertilization. In summary, most of the examples listed in column 6 of Table 1 indeed invite a direct search for maternal gene regulatory factors that are sequestered in the relevant regions of egg cytoplasm. Where there is invariant cleavage, these factors should be localized specifically to the appropriate blastomeres. In the case where the relevant regulatory factors are globally distributed but must undergo regional covalent alterations early in cleavage in order to attain functionality, then the problem would focus on the localized modification enzymes that carry out these alterations.

There is yet little direct evidence as to what is actually localized in cases of autonomous specification. Probably the best analyzed example of a localized maternal gene regulatory factor that affects subsequent cell fate specification in an autonomous way is that of the bicoid gene product in Drosophila (Frohnhöfer and NüssleinVolhard, 1986; Macdonald and Struhl, 1986, 1988; Nüsslein-Volhard et al. 1987; Struhl et al. 1989). Failure of maternal bicoid gene expression causes failure of anterior structures to form in the embryo, and severe mutants completely lack head and thorax. The bicoid mRNA is present at peak levels at the anterior end of
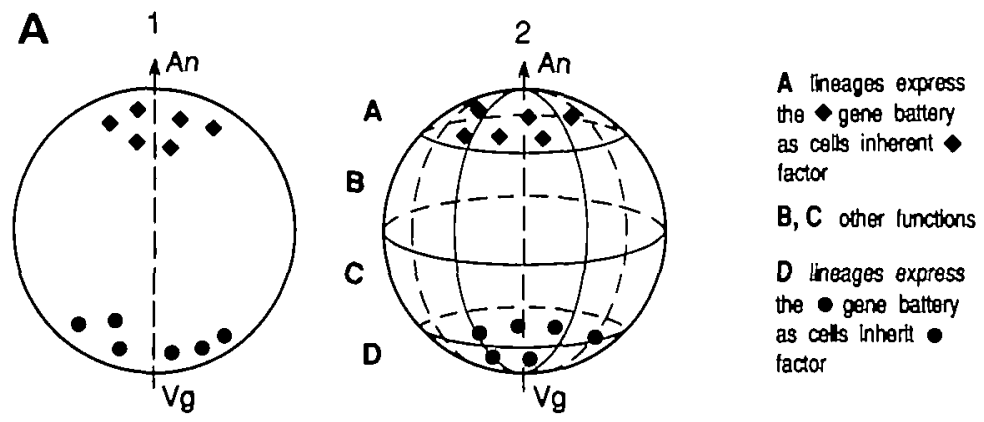

B
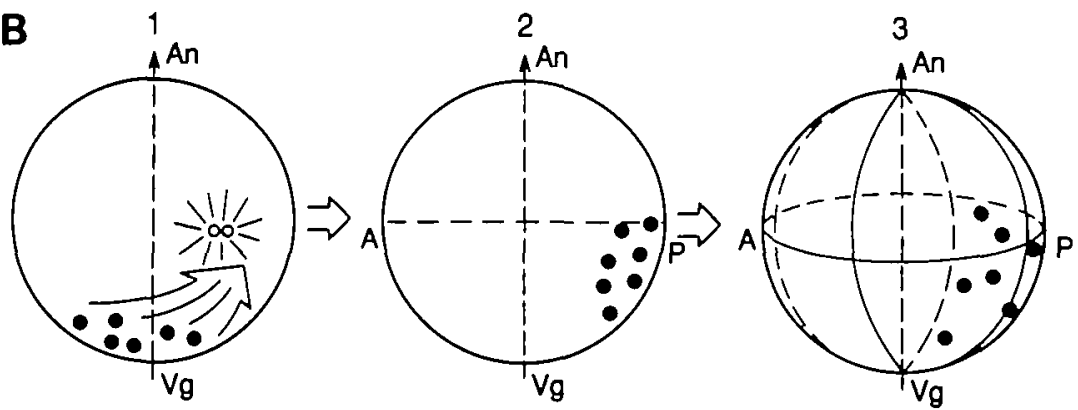

Fig. 1. Autonomous embryonic cell lineages, specified by inheritance of localized gene regulatory factors. In this mechanism, cell lineages are specified according to their inheritances of given regions of egg cytoplasm. The cell lineages resulting express specific genes autonomously, because the initial specification process neither depends upon nor involves intercellular interactions (irrespective of whether during later development the cells descendant from these initial lineages interact with one another or with other cells, or subsequently diversify in cell fate). In a, the regulatory factors $(\diamond, \bullet)$ are distributed at the poles of the preformed axis of the egg (A1), and are sequestered in early cleavages to lineages of tiers $A$ and $D$, respectively (A2). These blastomeres are thereby specified to become founder cells for autonomously specified lineages of different histospecific types. In b, a similar process is imagined, except that in this case the gene regulatory factors are localized by the mechanism establishing the position and polarity of the second axis. In this (not wholly) imaginary

example (see discussion of ascidian embryos in text), the fusion pronuclei serve as the organizing center for a cytoskeletal polarization that sets up the second (anterior-posterior, $\mathrm{A} / \mathrm{P}$ ) axis; the $\mathrm{An} / \mathrm{Vg}$ axis (here also the dorsoventral axis) is preestablished. Before fertilization the regulatory factors (O) are located at the vegetal pole (b1). As a result of the polarization, the gene regulators are drawn by contractile cytoskeletal elements to the future posterior end of the $\mathrm{A} / \mathrm{P}$ axis (B2). At cleavage (B3), they are sequestered into two cells which give rise to autonomously differentiating, histospecific posterior axial cell lineages. 
the embryo, and the protein is distributed in a declining concentration from anterior to posterior (Berleth et al. 1988; Driever and Nüsslein-Volhard, 1988a,b; Struhl et al. 1989). Anterior cytoplasm containing bicoid products can induce ectopic anterior structures when microinjected into bicoid mutant eggs, e.g. head structures in mid-regions and thoracic structures in abdominal regions accompanied by additional contiguous pattern derangements. Furthermore, the positions of the head fold at the head/thoracic boundary, and of diagnostic pair-rule gene expression patterns along the $\mathrm{A} / \mathrm{P}$ axis, depends directly on the shape of the concentration cline in the bicoid factor along this axis (Driever and Nüsslein-Volhard, 1988a; Struhl et al. 1989). The bicoid factor is a maternal homeodomain-containing protein, which has been shown in vitro to interact directly with cis-regulatory target sequences of hunchback, a zygotically expressed regulatory gene that, according to genetic evidence, requires the bicoid product for its activation early in development. The hunchback factor is a zinc finger regulatory protein, which is required in turn for the positional definition of the anterior regions of the embryo (see reviews of Akam, 1987; Driever and Nüsslein-Volhard, 1989; Struhl et al. 1989; Goto et al. 1989; for description, analysis, details and models proposing the downstream course of events by which the Drosophila egg is initially partitioned into the major $\mathrm{A} / \mathrm{P}$ regions of the larval body plan).

It is interesting to consider the case of bicoid mRNA and protein localization with reference to the examples of autonomous specification listed in Column 6 of Table 1. Though bicoid mRNA is indeed a maternal regulatory gene product that is sequestered in a primordially defined polar region of the egg cytoplasm, and that critically affects embryonic development, it differs from the examples in Table 1 in that it is not a histospecific regulator. It does not specify the autonomous differentiation of a given cell lineage or histospecific cell type. Instead, probably like many other homeobox genes, in Drosophila and other organisms, it indirectly affects the type and position of multiple subsequent programs of histospecific differentiation within a huge region of the embryo. That is, its immediate functions, so far as is known from molecular evidence, are to affect zygotic regulatory genes required for regional identity: to activate hunchback (Struhl et al. 1989; Driever and Nüsslein-Volhard, 1989), to repress the Krüppel regulatory gene (Gaul and Jäckle, 1987), possibly to interact as well with several of the pair rule genes, and there may be posttranscriptional effects of the bicoid product on other regulatory factors as well (Driever and Nüsslein-Volhard, 1988b; Rebagliati, 1989). However, the protein exists well beyond the time of execution of these known functions, and there may be additional functions yet undetected. Neither are these target regulatory genes, which are expressed zygotically, known to directly control any histospecific gene batteries (though this is not in any way excluded). The relation between the genes controlling the location of these regions (head, thorax, metameric units), i.e. so-called 'pattern formation' genes, and the later specification of histospecific cell types (muscle, nerve, etc.) remains wholly obscure. Definition of regional identity is not a property of the pattern formation gene or its product per se, but rather of the role it plays in early development, since later in development such genes are often found to be expressed in specific cell types, e.g. hunchback in segregating neuroblasts and ganglion mother cells (J. W. Posakony, pers. commun.); or $f t z$ and eve in specific sets of neurons (Doe et al. 1988a,b). In any case, to summarize the point of this discussion, localization of the bicoid factor and mRNA shows that maternal regional identity functions may indeed be spatially sequestered in the egg. However, it remains to be seen whether histospecific regulatory factors directly active in the early embryo are localized, such as would be required to explain most of the examples listed in Column 6 of Table 1.

From a comparative point of view, the complex system of maternal and early zygotic regulatory gene interactions by which are defined the initial spatial domains of the Drosophila embryo is a rather special device, the function of which is to divide a very large (in terms of the dimensions of the individual cells it later encompasses) two-dimensional space into a complex pattern, without using cells. The cascade of regulatory gene interactions initiated when localized maternal factors such as the bicoid product react with their immediate zygotic target regulatory genes takes place while the embryo is yet syncytial. Specification of histospecific cell lineages in the Drosophila embryo, a largely postgastrular event, follows rather than, as in other forms, constituting or preceding the identification of major embryonic regions, e.g. the head or tail.

\section{Conditional speciflcation}

Conditional lineage specification, as indicated above, is the more general process. Even in Drosophila, the terminal regions (e.g. Sprenger et al. 1989), dorsoventral specification and morphological organization within segments (see note $f$ of Table 1) all depend on conditional processes. A general mechanism by which conditional specification might occur was proposed for the sea urchin embryo (Davidson, 1989), in which this form of specification is particularly prominent. This interpretation requires that conditional specification could occur by activation of otherwise inactive gene regulatory factors, mediated by ligand-receptor interactions at the blastomere surface. In an embryo, the range of possible alternative fates that a given blastomere (and its progeny) may express would be defined by the set of potentially functional gene regulatory factors that it contains. If a given blastomere contains regulators that if active could elicit all of the possible initial states of specification (i.e. like the egg itself), it would approach the state that classical embryologists referred to as totipotency. In a more general case, the potentialities of a given lineage founder cell might be to express $\mathrm{X}, \mathrm{Y}$ or $\mathrm{W}$ gene batteries. Whichever of these is 
chosen for activation will start the cell lineage down its own (exclusive) histospecific course of differentiation. This blastomere, if in a given position in the embryo, might always express the $X$ battery, and become a founder cell for the $X$ lineage, but only because it receives an $X$-factor activating signal stemming from its reception of a particular ligand produced from the neighboring cells in that particular position. However, if the blastomere is moved to another position and hence receives a different signal, the $\mathrm{Y}$ or $\mathrm{W}$ batteries might instead be activated by the same mechanism. Thus the cells normally in the different positions where $\mathrm{X}, \mathrm{Y}$ and $\mathrm{W}$ lineages are founded are actually equivalent, and their specification is in each case conditional on the particular signal that they receive. The 'advantage' from the point of view of the embryo is escape from a requirement for multiple maternal factor sets to be spatially partitioned $a b$ initio into the right cells and escape from morphological rigidity, so that many different cells can play any specific role as the embryonic structure is built. (The flexibility of conditional specification potentiates the forms of development seen in higher vertebrates, where the embryo is built largely from migratory cells.) Thus, in our example, the regulative capacity of the blastomeres normally serving as founder cells for the $\mathrm{X}$ lineages, the $\mathrm{Y}$ lineages and the $\mathrm{W}$ lineages is in principle $(\mathrm{X}+\mathrm{Y}+\mathrm{W})$ for each.

A corollary of this argument is that in order for blastomeres to be pluripotent, or to have regulative properties, they must be endowed with a greater range of potentially functional, histospecific gene regulatory factors than they will utilize in any given situation. They must also mount the necessary diversity of ligand receptors and the ancillary signal transduction machinery that services these receptors. Thus they must be able to respond to any of several different ligands and the diverse ligands would be spatially more confined according to cellular positions in an embryo undergoing conditional specification than would be the receptors. For example, in Xenopus embryos, receptors for mesoderm inducing ligands of the Fibroblast Growth Factor (FGF) family are present in cells in all regions of the embryo, including vegetal cells that in undisturbed embryos never form mesoderm (Gillespie et al. 1989). We might thus suppose that primordial anisotropies in the egg are utilized to localize ligands, or mRNAs for ligands. For example, the $V g_{l}$ mRNA of Xenopus eggs, which codes for a TGF $\beta$-like ligand probably involved in the conditional specification of axial mesoderm, is localized to the vegetal pole of the egg (Weeks and Melton, 1987). $V g_{1}$ mRNAs are localized to the vegetal pole of the egg during oogenesis (Melton, 1987), where they may be associated with the cytoskeleton and are inherited by the vegetal endoderm cells early in cleavage. The autonomously specified skeletogenic precursor cells of the sea urchin egg possess a special capacity to induce gut formation in any cells they are placed adjacent to (Hörstadius, 1939) just as they apparently do in their normal position to the overlying $\left(\mathrm{Veg}_{2}\right)$ tier of blastomeres. It would be predicted that these skeletogenic precursor cells thus also express a special set of ligands (Davidson, 1989). An example in the Drosophila embryo is provided by the product of the gene decapentaplegic, which codes for a protein that is also a member of the TGF $\beta$ family (Padgett et al. 1987). This is an early zygotic gene product expressed in the dorsal epidermis (St. Johnston and Gelbart, 1987), which is probably involved in a signal transduction required for the specification of cells along the preformed dorsal-ventral axis. In general, as any blastomere becomes specified, whether by autonomous or conditional routes, it might, as an element of its package of activated functions, express a new set of (therefore) spatially confined ligands. This concept provides a dynamic explanation for regulative respecification. Regulative development has to be spatially organized, since pluripotential cells that normally would be channelled by intercellular signalling into a given fate must now be channelled into different fates in the right positions. The essentials of such a mechanism are illustrated in the cartoon in Fig. 2.

In the terms of this discussion, an invariant cleavage pattern, if utilized in a conditional specification system, might have a mechanistic significance that is entirely distinct from the classical assumptions that canonical cell lineage implies a mosaic of autonomously differentiating cell types. This is that invariantly positioned cleavage planes provide exact locations in the embryo for the ligand-receptor interactions that would be required to specify adjacent blastomeres. This ensures that given states of specification will occur in the appropriate spatial elements of the embryo. A following implication is that in small embryos, such as Strongylocentrotus or C. elegans, i.e. embryos that have invariant cleavage but also display extensive conditional specification processes (cf. Table 1), the ligands may be bound to the presenting cells, so as to use the complex spatial information available in the cleavage planes with the highest possible resolution. Thus certain cleavage planes come to separate founder cells of different fates. On the other hand, in large eggs with variable cleavage, e.g. anuran eggs, the exact geometry of the cleavage planes cannot be so important and the ligands might usually be diffusible, affecting regions of the embryo irrespective of the exact local lineage.

\section{Regulatory factors that might effect conditional specification}

Except for mammalian embryos, which from the earliest stages take up nutrients from the fallopian environment, all of the embryo types listed in Table 1 are essentially closed systems. During specification there is no net growth in the embryo as a whole, and the cytoplasmic volume of each early cleavage stage blastomere is divided between its offspring and then divided again at the next cleavage, and so forth. Thus, if a given cleavage stage blastomere is specified as a lineage founder cell, all of the progeny of which will clonally express the same functions, the cytoplasm of the founder cell that is shared amongst the progeny can be regarded literally as a regulatory domain. Within this domain the nuclei of the clonal lineage will all be 


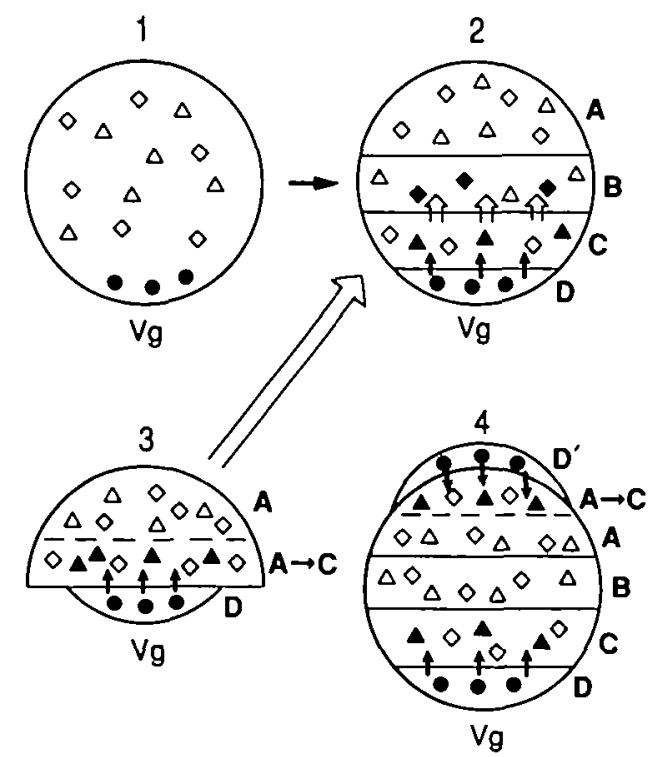

exposed to the same set of functional regulatory factors, and will express the same genes. In most forms and for most cell lineages, conditional specification is the major mechanism by which such embryonic regulatory domains are created, though as Table 1 implies regulatory domains are also created in many embryos by autonomous specification processes. In conditionally specified domains, given factors are activated (or deactivated), but not in contemporary adjacent domains of differing fate. Though for simplicity this has not been added at each juncture, the same arguments of course pertain to factors that when activated promote gene expression as to factors that when activated function negatively, as repressors of gene expression.

Many excellent examples are known of regulatory factors the activity of which is altered in response to ligand-receptor interactions. The steroid hormone receptor family is a special class of such factors, which is developmentally important at least in some systems. Retinoic acid, the receptor for which is a member of this family, is a probable morphogen in avian, amphibian and mammalian systems (Edwards and McBurney, 1983; Maden, 1985; Thaller and Eichele, 1987; Giguere et al. 1989; Durston et al. 1989). Receptors of this family serve per se as gene regulatory factors, activated directly by their ligand, and there is no requirement for the biochemical signal transduction systems utilized by other classes of ligand receptor. On the other hand, the activity of a number of other mammalian transcription regulatory factors has been shown to be inductively altered in response to signal transduction events. Among these are the serum response factor, which is activated via some yet unknown alteration by various mitogens (Norman et al. 1988); several factors that act to derepress the $\beta$-interferon gene in response to external signals (Goodbourne and Maniatis, 1988; Fan and Maniatis, 1989, 1990); the CREB factor, which responds to cAMP stimulation (Delegeane et al. 1987); and $a$ factor that interacts with and inhibits the NF- $K B$ transcription factor (Baeuerle and Baltimore, 1988).
Fig. 2. Example of conditional lineage specification. A simplified model of the sea urchin embryo is shown, abstracted from the more detailed interpretation given in Fig. 5 of Davidson (1989). In this simplification, tier A represents the $\left(a n_{1}\right.$ and $\left.a n_{2}\right)$ tiers of the 64-cell embryo, i.e. the animal blastomere cap; B represents the veg 1 tier; C, the $v_{e g}$ tier; $D$ the micromere precursors of the skeletogenic lineages. For the ultimate fates of these tiers and the developmental territories into which they are divided see Fig. 3b. In 1, an egg is shown containing a localized active regulatory factor $(\bullet)$ that promotes expression of skeletogenic genes attached at the vegetal pole $(\mathrm{Vg})$, and two other factors, $(\diamond)$ and $(\Delta)$, that are otherwise globally distributed. The open symbols denote that these factors are present as a set of inactive forms. Inactive forms of the vegetal skeletogenic regulator, i.e. $(O)$, must be present elsewhere as well, but are omitted for simplicity, as are factors required for specification across the oral-aboral axis (cf. Davidson, 1989). In 2, cleavage has separated the vegetal cell tier containing the localized active factors (O) into a set of lineages D (vertical cleavage planes are not shown), and overlying tiers consisting of lineage sets $\mathrm{C}, \mathrm{B}$ and $\mathrm{A}$. However, the property of the D lineages, in addition to expressing the gene battery controlled by the (-) regulators, is to mount on their upper surface, here the $C / D$ interface, an inductive ligand $(\uparrow)$. In the adjacent cells, i.e. those of the C-tier, this ligand interacts with a receptor (not shown). Signal transduction results in conversion of the inactive $(\Delta)$ factor to an active form symbolized as the filled symbol $(\boldsymbol{\Delta})$. The other regulator shown $(\diamond)$ is not directly affected by this specific signal transduction system. The $C$ lineages now express lineagespecific genes controlled by the $(\boldsymbol{\Lambda})$ regulatory factor, and they also, in turn, mount on their upper surfaces a different ligand $(4)$ that interacts with receptors on the $B$ tier of cells. The resulting signal transduction in the $\mathrm{B}$ tier activates a different set of lineage specific factors $(\bullet)$. The consequence is activation of $\mathrm{B}$ gene batteries. While the initial specification of the $D$ lineage is autonomous, as in Fig. 1, specification of the $C$ and $B$ lineages is conditional, since both these specification events depend on interactions with adjacent cells, and the regulatory molecules that respond to these interactions are all present in A, B and C cell tiers. This endows all three of these tiers with the regulative potentiality for alternative specifications. This is illustrated in parts 3 and 4 using the C-lineage functions normally controlled in that cell tier by the $(\mathbf{A})$ regulator. In 3 , the animal cap, $A$, is combined with tier $D$, and the result is induction of C-lineage functions in the adjacent set of cells formed as cleavage progresses. In 4, an extra D tier $\left(D^{\prime}\right)$ is placed on top of the embryo, and C-lineage functions are now induced in the contiguous cells of tier $\mathrm{A}$ as well as in tier $C$. In the sea urchin embryo, where $C$ is the tier that gives rise to archenteron, the result of this operation (i.e. animal implantation of micromeres) is induction of a secondary archenteron. It follows that tier A must contain the regulatory factors that are required to activate the C-lineage gene pattern, here symbolically represented in their cryptic or inactive form $(\Delta)$, pending the inductive influence mediated by the $D$ ligands, either in normal (2) or chimeric ( 3 and 4 ) development.

This inhibitory factor inducibly alters the activity of the $\mathrm{NF}-\mathrm{KB}$ protein, which is required for expression of kappa light chain immunoglobulin genes in B-cells, the 
IL-2 lymphokine gene in T-cells and other lymphoidspecific genes (Sen and Baltimore, 1986; Atchison and Perry, 1987; Hoyos et al. 1989). In all of these cases, the DNA-binding regulatory factors are always present, with respect to cell type, or are widespread with respect to cell type. However, their activity depends critically on the advent of appropriate ligands which stimulate specific receptors, thus mediating intercellular biochemical changes that modify the regulatory factors. Formally these examples resemble the mechanism proposed here for conditional specification in the embryo. In most cases where inductive ligands are known or suspected in embryos, the ligands are proteins belonging to various growth factor families. Among the latter are members of the FGF family, and the TGF $\beta$ family, implicated in early embryo induction in Xenopus (Smith, 1987; Kimelman and Kirschner, 1987; Slack et al. 1987; Grunz et al. 1988; Rosa, 1989) and in Drosophila (e.g. decapentaplegic, discussed above). In Xenopus embryos, $\mathrm{Li}^{+}$changes the fate of cells that are conditionally specified by induction (Kao et al. 1986; Kao and Elinson, 1989; Slack et al. 1988; Klein and Moody, 1989) and it apparently does so via the phosphoinositide signal transduction system (Busa and Gimlich, 1989). Members of the EGF family are also functional in conditional specification during embryogenesis, but in known cases apparently act as receptors. Examples of members of this family required in early development include lin12 and glp-1 in C. elegans and Notch in Drosophila (Greenwald, 1985; Wharton et al. 1985; Kidd et al. 1986; Yochem and Greenwald, 1989). In other instances, in mammalian cells, a different kind of regulatory factor response follows ligand-receptor interactions and signal transduction. Rather than activation of preexistent factors, synthesis of new transcriptional regulatory molecules is stimulated by the extracellular signal. Two cardinal examples are the c-fos protein, which in response to mitogens is involved in activation of a great number of cellular growth genes (Curran, 1988; Sassone-Corsi et al. 1988; Fisch et al. 1989), and NFAT1, an essential inductive regulator of the IL-2 gene in T-cells that appears in consequence of ligand binding by the T-cell receptor complex (Crabtree, 1989). Is conditional specification in embryos likely to function by this latter means rather than by modification of preexistent (i.e. maternal) factors? This is not an unlikely scenario for teleost, avian or mammalian embryos, in which definitive cell specification occurs after cleavage, and in mammals after implantation, long past the time when most maternal mRNAs are largely exhausted (see Davidson, 1986, pp. 100-104). However, it is much less likely in other cases. Thus, for example, two cloned sea urchin embryo factors, at least one of which is involved in histospecific conditional specification processes in the aboral ectoderm, are both maternal (F. Calzone, C. Höög, A. Cutting, unpublished data). In amphibian embryos, at least some inductive specifications take place during the period of transcriptional quiescence that lasts until midblastula stage. These events are likely to be mediated by factors that are encoded by maternal mRNAs if not by maternal protein factors per se. In this connection, Cascio and Gurdon (1987) showed that protein synthesis is in fact required for successful muscle gene induction to occur in Xenopus embryo explants at these early stages.

To close this part of our discussion, it is interesting to speculate on the regulatory complexity required to generate the initial set of differentially functioning cell types in embryonic space. One's impression is that an embryo does not start off with a great many different cell types, counting only the initial cohort that can or could be detected with molecular probes as early as differential gene function appears. In the sea urchin embryo, five cell fate 'territories' can be distinguished in the blastula, two of which are well defined in terms of differential gene expression, and ultimately in their histospecific character (Davidson, 1989). Similarly, at least in the posterior end of the C. elegans embryo, there are a small number of autonomously specified clonal cell lineages, some of which express histospecific genes within a few cleavages, such as gut and body muscle (reviewed by Davidson, 1986, pp. 209-212); and in amphibian and ascidian embryos we can discover notochord, muscle, gut, neural plate, etc. Of course most (though not all) of these embryonic territories diversify later on, through extensive further interactions and brachiations of cell fate, but that is another story. In embryos that begin by specifying cellular regulatory domains, either by conditional or autonomous processes, a relatively small number of such domains may suffice. Thus even including genes coding for ligands and receptors, the genes specifically involved in organizing the first set of differential spatial patterns of histospecific gene expression may amount to only a few percent of the total complexity of the mRNA populations being translated on the early embryo polysomes.

\section{Interpretation of some speclal comparative problems}

A riddle of conditional and autonomous specification: why are different modes of specification sometimes used for the same cell types in the same embryo and in closely related forms?

Table 1 includes references to three examples in which specification of a given cell type (or types) is accomplished in completely different ways when this would not be expected a priori. In two of these cases, specification of axial muscles in the ascidian embryo and of pharyngeal muscles in the C. elegans embryo, both autonomous and conditional specification are used in different regions of the same structure. A similar paradoxical variation exists in the means by which occurs the specification of lineage founder cells for axial muscle and intestine in different gastropod molluscs. In ascidian embryos, the majority of body muscle cells form autonomously in lineages descending from the two 3rd cleavage cells (the right and left $\mathbf{B 4 . 1}$ cells) that inherit a localized section of maternal cytoplasm known 
as 'myoplasm' (Table 1; see experiments of Whittaker, 1980, 1982, 1983; Whittaker et al. 1977; Crowther and Whittaker, 1983; Deno and Satoh, 1984; Nishikata et al. 1987a; Jeffery, 1989; reviewed in Davidson, 1986, pp. 430-436). In Ciona species, e.g., 12 of the 16 muscle cells in each half-embryo descend from each B4.1 cell. However, the four muscle cells that are the most caudal in position have a wholly different lineage. Two of these cells derive from the 3rd cleavage $\mathbf{A 4 . 1}$ blastomere and two from the b4.2 blastomere. In another genus, Halocynthia, five caudal tail muscle cells in each half embryo descend from each b4.2 blastomere (Nishida and Satoh, 1983, 1985; Zalokar and Sardet, 1984). The progenitors of the muscle cells that arise from the A4.1 and $\mathbf{b 4 . 2}$ lineages appear to be specified conditionally, in contrast to those arising autonomously from the B4.1 blastomeres, even though all of these body muscles express the same histospecific muscle markers, so far as is known. In $80-100 \%$ of cases, progeny of the B4.1 blastomeres isolated at any successive stage of cleavage produce muscle markers, the best known of which is acetylcholinesterase, in subsequent culture, but this occurs, if at all, in only a few percent of the time in cultured A4.1 or b4.2 progeny (Deno et al. 1985). The most significant difference is revealed by cytochalasin treatment, which arrests cytokinesis but not nuclear replication. Cytochalasin thus generates syncytial, multinucleate cells with the recognizable boundaries of the blastomeres present when the drug was added. When ascidian embryos are treated with this agent at third cleavage and cultured, the $\mathbf{B 4 . 1}$ cells express a number of specific muscle markers, including myofibrils, various muscle antigens, muscle actin, ion channels and acetylcholinesterase, and, if treated at later cleavages, whatever muscle lineage cells descendant from the B4.1 cells are then present express these markers (Whittaker, 1973; Satoh, 1979; Davidson, 1986 op. cit.; Jeffery, 1989; Takahashi and Yoshii, 1981). In contrast, in cytochalasin-treated embryos, muscle markers are never observed in the progeny of $\mathbf{b 4 . 2}$ blastomeres, and only in a few percent, at low levels, in progeny of $\mathbf{A 4 . 1}$ blastomeres, though as we have seen b4.2 and $\mathbf{A 4 . 1}$ blastomeres normally give rise to the caudal tail muscles. Thus the $\mathbf{B 4 . 1}$ cells develop muscle markers autonomously, while specification of the adjacent muscle cell progeny of $\mathbf{A 4 . 1}$ and b4.2 occurs conditionally, apparently requiring intercellular interactions that cannot take place when the progressive cellularization of the embryo is blocked.

A very similar example has come to light in the $C$. elegans embryo. Priess and Thomson (1987) and Priess et al. (1987) showed that the pharyngeal muscle cells of the anterior end of the digestive tract derive from five progenitor cells, the two posterior of which are apparently specified autonomously, while the anterior three are clearly specified by an early intercellular interaction occurring between the 4-cell and 28-cell stages. Both resulting sets of pharyngeal muscle cells express the same pharynx-specific myosin isoforms (Epstein et al. 1982). If the posterior blastomeres that evidently serve as the source of the inductive ligand are ablated, the anterior pharyngeal precursors (viz. descendants of the ABa cell) express other fates, although such contiguous ablations do not affect the specification of the posterior pharyngeal precursors ( $v i z$. descendants of the MS cell). It should be noted in passing that the majority of the body wall muscle cells in $C$. elegans arise from posterior founder cells (viz. Cpp, Cap and D), which also appear to be specified autonomously. Returning to the origin of the anterior pharyngeal muscle precursors, if the $\mathbf{A B p}$ cell is exchanged in position with the $\mathbf{A B a}$ cell, it instead produces these precursors. Furthermore, a gene called $g l p-1$, which codes for a transmembrane protein of the EGF family and also mediates intercellular interactions in gonadogenesis (Austin and Kimble, 1987, 1989; Yochem and Greenwald, 1989), is required for embryonic specification of the ABa pharyngeal precursor cells. In $g l p-1$ mutants, the cells that would have given rise to pharyngeal muscles instead produce neurons (Priess et al. 1987). Thus, just as in the ascidian case, adjacent regions of the same histospecific structure derive from precursors, some of which are specified autonomously, and others of which are specified conditionally.

A contrast of similar import can be seen in the means by which the dorsal-ventral axis is formed in equally and unequally cleaving gastropod molluscs (the Ilyanassa embryo, included in Table 1 , is an example of an unequally cleaving form). At first cleavage, in the unequal cleaving forms, an element of maternal cytoplasm then located at the vegetal pole is extruded as the 'polar lobe', and as the cleavage terminates, this cytoplasm flows back into either one or the other of the two wholly equivalent macromeres. The polar lobe is connected to the remainder of the egg by a very thin cytoplasmic strand, and the choice of which macromere is to receive the lobe cytoplasm is apparently an accidental consequence of the position of the first cleavage plane as it penetrates the egg cytoplasm from the animal pole, segregating the connecting strand to one blastomere or the other. The macromere receiving the polar lobe cytoplasm (viz. the CD macromere) is thereby autonomously specified as the posterior one (Guerrier et al. 1978). Later in cleavage the D macromere, which retains the polar lobe cytoplasm, will produce the $\mathbf{M E}_{1}$ and $\mathbf{M E} \mathbf{E}_{2}$ mesoderm founder cells and the $\mathbf{E}_{1}$ and $\mathbf{E}_{2}$ intestine founder cells mentioned earlier. The progeny of these cells generate the major axial structures of the embryo (reviewed by Davidson, 1986 , pp. 453-473). However, in equally cleaving molluscan eggs, including those of some other gastropod genera, such as Patella and Lymnaea, no polar lobe is formed, and in contrast to examples such as Ilyanassa, where only the $\mathbf{D}$ macromere retains this capacity, all four 2 nd cleavage macromeres can equally give rise to the axial cell lineages (i.e. the $\mathbf{M E}$ and $\mathbf{E}$ lineages). Once these lineages appear they are obviously homologous to those generated autonomously in the dorsal posterior quadrant of the unequally cleaving eggs of organisms that belong to the same taxonomic subclass, as for example do Ilyanassa and Patella. In Patella and Lymnaea eggs, the dorsal quadrant is not established until 5th cleav- 
age. It is then specified by a conditional, cellular interaction process, which can equally well occur in any quadrant, between the pluripotential micromeres at the animal pole of the egg and whichever of the pluripotential macromeres first encounters these micromeres as they extend upward across the incipient blastocoel (van den Biggelaar and Guerrier, 1979; Arnolds et al. 1983; see review in Davidson, 1986, pp. 462-467). Thus here again, we seem to have both a conditional (Lymnaea and Patella) and an autonomous (Ilyanassa) specification mechanism utilized to accomplish the same ends, in particular, the specification of the homologous $\mathbf{M}$ and $E$ lineages.

In each of these three cases, the invariant cleavage geometry is clearly utilized to position histospecific precursor cells that are specified by conditional mechanisms. Since the ultimate patterns of gene expression in the conditionally and autonomously specified components considered in each example are probably the same, the terminal regulatory elements, i.e., histospecific gene batteries and their activating factors, are also probably the same. Interpreted in the terms of the propositions in the previous section, the difference between the autonomous and conditional components could simply be one of timing. Suppose that some gene regulatory factors that are required for activation of the relevant histospecific gene batteries must be modified in order for them to be functional. In autonomously specified components of the embryo such modifications must occur during oogenesis, or at least prior to the definitive localization of these factors as cleavage begins, while in the conditionally specified components the same modifications are triggered by signals received from the (appropriately positioned) adjacent blastomeres. A heterochronic variation might thus be transformed into a basic difference in how these elements of the embryo work: late modification yields plastic, regulative founder cells emplaced with respect to their neighbors; early modification implies inflexible autonomous founder cells that may provide spatial coordinates for their neighbors. The same mechanism in slightly different temporal context yields dramatically different developmental phenomenology.

\section{The cytochalasin experiments and the concept of the cytoplasmic regulatory domain}

Cleavage arrest of ascidian embryos with cytochalasin is permissive of several other histospecific gene expressions, in addition to the various muscle markers. Thus, for example, gut alkaline phosphatase appears in the syncytial lineage elements whose progeny are destined normally to form gut, and there are equivalent observations for histospecific, cytological notochord markers (Whittaker, 1977, 1979; Crowther and Whittaker, 1984). In each of these cases the cytoplasm of the progenitor cell at the stage of arrest evidently constitutes a specified regulatory domain that suffices to impose a particular differential gene function. This is true for both autonomously and conditionally specified cell lineages, in the latter case so long as the cytochalasin is introduced after the specification event. In ascidian embryos, for example, the brain, the otolith and ocellar melanocytes therein, and the palps are inductively specified (Reverberi et al. 1960; Ortolani, 1987). The interactions required for specification of these pigment cells apparently occur by 6 th cleavage (Nishida and Satoh, 1989), and embryos treated with cytochalasin at this stage and later still reveal the normal two pigment cells. Cleavage arrest with cytochalasin permits the expression of autonomously specified, histospecific lineage markers in $C$. elegans embryos as well, including gut, hypodermis and muscle markers (Laufer et al. 1980; Cowan and McIntosh, 1985). The best characterized example is provided by the $\mathbf{E}$ blastomere lineage, which produces gut exclusively. Thus, Edgar and McGhee (1986) showed that whatever number of cells belongs to the $\mathbf{E}$ lineage at the moment of cytochalasin arrest will express a gut-specific esterase. That the cytochalasin experiments 'work' in these two organisms, is consistent with the concept of the cytoplasmic regulatory domain, which is defined in molecular terms by its content of functional gene regulatory factors. Thus they work in part because gene regulatory factors have nuclear localization signals; because there is a normal cytoplasm-to-nuclei ratio within the syncytial blastomeres resulting from cytochalasin treatment, i.e., comparing the total number of nuclei and total amount of cytoplasm that would normally have been included in the progeny of an arrested blastomere (there is no net growth in the untreated cleavage stage embryo); and because once specification has occurred there is no requirement for further intercellular interaction within the domains, so that whether it is cellularized or not is inconsequential.

If cleavage is arrested with cytochalasin before segregation of diverse autonomously regulated lineages from given blastomeres, two different classes of result might be obtained, in the limit, even if the drug is introduced at the zygote stage. If all autonomous gene regulation programs operate independently, then the blocked cell should express histospecific genes that represent all of those different gene batteries at once, for which there are preformed (i.e. maternal) positive regulatory factors. On the other hand, if these programs interfere with (i.e. repress) one another, then some sort of 'extinction' or dominance effect such as is often observed in cell fusion experiments might be expected, in which only a fraction of the possible range of programs is expressed. In the event, examples of both these alternatives have been reported. Thus Crowthers and Whittaker (1986) showed that in individual syncytial 1-cell Ciona 'embryos' generated by treating zygotes with cytochalasin, markers of two, three or four different states of differentiation all appear. These include muscle myofibrils and muscle tropomyosin identified immunologically (R. Whittaker, pers. commun.), acetylcholinesterase and ultrastructural organelles specific to notochord, neural and epidermal cell types. In zygote and early cleavage arrested embryos of another ascidian genus (Halocynthia; Nishikata et al. 1988), epidermal antigens are reported to be expressed in cytochalasin-treated embryos, but to the exclusion of 
a muscle antigen. After the muscle lineage segregates out (i.e. after 3rd cleavage), cytochalasin treatment reveals this muscle antigen as well in the appropriate blastomeres. Nor in Styela does muscle actin mRNA appear in embryos arrested with cytochalasin prior to 3rd cleavage (Jeffery, 1989). Similarly, cytochalasintreated $C$. elegans zygotes produce only hypodermal markers, while, after 1st cleavage, gut markers, hypodermis markers and muscle markers are produced by the P1 cell (which is normally ancestral to all three types of lineage) and only hypodermis markers are produced by the AB cell (Cowan and McIntosh, 1985; Edgar and McGhee, 1986). These and other examples in which the number of different programs is less than the number expressed by the immediate, autonomously specified progeny of given early cleavage blastomeres suggest that negative regulatory factors are not uncommon and that they constitute part of the 'package' of maternal factors inherited by autonomously specified blastomeres. The positive results obtained, on the other hand, in all probability require that the egg indeed contains positively acting, histospecific regulatory factors, for which cell interaction is not required to mediate a state of functionality. These observations do not exclude the possibility that in the normal egg the localized elements are enzymatic functions that regionally activate widely distributed regulatory factors, so long as this can occur without cells or cell interaction, but they do exclude an autocrine mechanism (for these examples). In summary, these cytochalasin experiments transform into a physical reality the conceptual image that the whole of an autonomously specified, clonally differentiating embryonic cell lineage constitutes a regulatory domain that consists essentially of the gene regulatory factors resident in the founder cell cytoplasm, which during cleavage are partitioned amongst its descendants.

\section{The 'salt-and-pepper' specification of cell fate in advanced teleost and anuran embryos}

The use of reliable individual cell lineage tracers, such as injected horseradish peroxidase or the fluoresceinated dextrans, has in the last few years revealed a striking feature of amphibian and higher teleost embryogenesis, which presents a major problem in understanding. This is that individual blastomeres, far into cleavage and even blastula stage, may each give rise to a great number of different cell types, and these are different not only one from another, but from one embryo to another. In these organisms, the progeny of given labeled blastomeres in general migrate extensively after cleavage is terminated and come to lie in various structures, where they express a large number of diverse cell fates. The most extreme well-authenticated example is the Brachydanio (zebrafish) embryo in which there is no cell of the cleavage- or blastula-stage embryo for which the above description does not seem to hold (Kimmel and Law, 1985a; Kimmel and Warga, 1986; 1987a,b; 1989; Kimmel et al. 1990). In Xenopus embryos, all vegetal pole blastomeres of 32-cell stage embryos contribute to the endoderm, as do the vast majority if not all of their progeny (Gimlich and Gerhart, 1984; Heasman et al. 1984; Moody, 1987a; Dale and Slack, 1987); and by the 512-cell stage most cells of this region display exclusively endodermal fates (Jacobson and Xu, 1989; Heasman et al. 1984), unlike any cells in the midblastula Brachydanio embryo. Whether this is only because in Xenopus these cells lack mobility (Wetts and Fraser, 1989) or because there is in this embryo autonomous endoderm specification (Wylie et al. 1987) is not yet clear. However, virtually all the other Xenopus blastomeres tested, from 5th through 9 th cleavage, produce some progeny that are diverse in histospecific type. Characteristically these progeny migrate to various regions of the embryo and participate in the formation of various embryonic structures (Keller, 1976; Dale and Slack, 1987; Moody, 1987b; Jacobson and Xu, 1989; Wetts and Fraser, 1989; reviewed by Davidson, 1986, pp. 250-258). Thus mapped on the late cleavage (premigratory) blastular sphere, the progeny cell fates observed in detail present a 'salt-and-pepper' aspect (the phrase belongs to Dale and Slack, 1987) rather than appearing as a series of contiguous regions or blocks, each destined to form a given structure or cell type.

In teleost and amphibian embryos, such cell fate block diagrams are useful only if understood as statistical representations (as stressed earlier elsewhere: cf. Davidson, 1986, pp. 250-258; Dale and Slack, 1987; Kimmel, 1989). In regard to prospective mechanisms of specification, there is of course a fundamental distinction between a process that converts all the cells in a given region of an embryo into a certain cell type, and a process that generates a certain probability that any given cell will give rise to a specific cell type; another probability that it will give rise to a second cell type; and lower probabilities that several other cell types might also arise from it. The probabilities in question (obtained from comparing results on different individual embryos) range anywhere from one or a few percent to over 90 percent. In systems using this mechanism, commitment is a necessary feature because the cellular environment of any given blastomere is continuously changing. 'Salt-and-pepper' cell fate distribution and the probabilistic specification processes underlying this phenomenon, are clearly dominant mechanisms of postimplantation mammalian embryogenesis as well (e.g. see Beddington, 1983; Gardner et al. 1985; Rossant, 1985; Lawson et al. 1986; Cockroft and Gardner, 1987).

Comparative considerations again remind the observer of the profound effects of reversal in the order, or timing, of developmental processes. In Brachydanio, for example, Kimmel and Warga (1986, 1990) and Kimmel et al. (1990) observed that only when labeled at gastrulation are the progeny of given marked cells restricted to the same cell type. In this embryo, many of the cells appear unspecified until the time of gastrular involution. Some may become specified just before this, during blastular migration (epiboly), and others only later, when they take up positions in the future endodermal and mesodermal layers of the embryo. Thus 
specification could be mediated by intercellular signals deriving from the adjacent cells during a relatively late temporal window of competency to respond. In Brachydanio, the original relation between cleavage stage progenitors of given blastomeres appears to be of no significance whatsoever in the specification process. But the product of this heuristic thought is the realization that it probably goes too far. The primordial animalvegetal organization of the egg is retained in the blastoderm of the embryo (Kimmel and Law, 1985b; Kimmel and Warga, 1990), and the establishment of the second or anterior-posterior axis, however that occurs, no doubt precedes cell specification at the later blastula-gastrula stages. That is, the cells of the blastodisc, or at least some of them, must have imposed upon them prior to establishment of histospecific cell lineages, a biaxial and regional specification. One component of this axial specification system may be the underlying yolk cell, since in Salmo embryos the bilateral polarity of the yolk cell may be imprinted anew on transplanted blastodiscs (Long, 1983). In any case, all the lineage and cell fate data suggest that in teleost embryos, masses of migratory cells are recruited to the various already defined regions of the embryo where their histospecific fates diversify according to local position (Ballard, 1973; Kimmel and Warga, 1990; Kimmel et al. 1990). This suggests that some genetic regional specification functions in this embryo must precede any histospecification functions, a matter further taken up below in the final subsection of this essay. In the sea urchin or ascidian embryos, to consider two contrasting examples amongst deuterostomial organisms, at least some major histospecification functions have already been completed even before cleavage is over.

In Xenopus, there is direct evidence for some specification processes during later cleavage, including histospecific ones. There is again a long lasting (until gastrulation) plasticity, ultimately much cell migration, and, as noted above, a salt-and-pepper pattern of histospecific lineage specification. Blastomere and graft transplantation experiments certainly demonstrate the continued totipotency of most cell types (except endoderm and the outer layer of ectoderm) well into gastrulation (Heasman et al. 1984; Jones and Woodland, 1986, 1987a; Snape et al. 1987). However, the timing of commitment does not indicate the stage at which conditional specification actually takes place, or begins to take place, but only the point at which it can no longer take place. The best analyzed case is mesoderm induction. Diffusible inducing ligands originating from vegetal cells, probably of the $\beta$ TGF and FGF ligand families (reviewed by Ruiz i Altaba and Melton, 1989a; Slack et al. 1987; Smith, 1987; Kimelman and Kirschner, 1987), affect overlying, plastic cells of the animal cap, some fraction of which are thus specified as axial mesoderm. In experimental arrangements in which inducing vegetal cells are placed together with competent animal cap cells, the inducing capability is evidently present as early as the 32-cell stage, if not before, and induction may have occurred by 7 th- 8 th cleavage, though both competence and induction can be demonstrated thereafter (Nakamura et al. 1970; Gimlich and Gerhart, 1984; Gurdon et al. 1985; Jones and Woodland, 1987b). Therefore, in this example, conditional specification of a histospecific cell type by defined ligands clearly precedes migratory dispersion of cells whose progeny will later express axial mesoderm markers. It also precedes gene transcription and commitment.

Fate maps that purport to show axial mesoderm arising from those blastomeres that are in contact with vegetal inducing cells notwithstanding, the actual process is much more interesting. During mid-cleavage, when this induction is occurring, the receiving (as well as inducing) cells are relatively large. In the successive cleavages, the cytoplasm of these cells will be partitioned amongst their progeny. The process that must actually occur is one in which the cytoplasmic domains of the cells initially receiving the signal is altered in some way by this signal, but not all of the progeny that share this cytoplasm become axial mesoderm. In fact, these marginal zone blastomeres of the animal cap are in statistical terms extremely pluripotent, and their progeny contribute in normal undisturbed embryos to ectoderm, CNS and endoderm, as well as to all mesodermal cell types (see cell lineage references above). Two different ways to interpret this phenomenon, i.e. an induction, the effect of which is only to tilt the probabilistic outcome in the direction of axial mesoderm, are as follows. It is possible that the regulatory factors affected by the inductive signal, or the signal transduction machinery that mediates the inductive effects, are particulate, or are associated with elements of the cytoskeleton that are polarized. When the cell divides, some offspring would receive the activated factors, and some would not (or would receive other activated factors). A second general class of explanations is that the biochemical pathways through which the signal transduction proceeds have branch points, where a reaction may or may not happen, or inhibitors, so that for each given signal input there is only a certain probability, less than one, of obtaining the output. Then, if in a given progeny cell the result is negative, that cell would be channeled to adopt a different fate upon a subsequent signal, etc. Or different signals could compete simultaneously. Basic components of this kind of cytoplasmic regulatory logic are that it has negative as well as positive elements, and that cells communicate in order to preserve an appropriate outcome. Such a process might provide a guide to understanding why ectopic recombination experiments may give quantitatively different results than what, according to lineage studies, actually happens in the undisturbed embryo. For example, in experiments in which all of a mass of target animal cap cells is induced to activate muscle actin, as when they are surrounded as in a sandwich by inducing cells (Gurdon, 1989), the outcome may depend on a greatly increased signal, compared to the normal case. 
Whole sea urchin embryos from quadrants: regulation of histospecific genes in regulative reconstruction In 1891 and following years, Hans Driesch published the astounding observation that a quarter sea urchin embryo, i.e. a single 2 nd cleavage blastomere, could if allowed to develop in culture reestablish a whole normal embryo that would produce a normally constructed larva (Driesch, 1891, 1900). All four 2nd cleavage blastomeres of a given embryo in fact reproducibly display this capacity (Boveri, 1907; Hörstadius and Wolsky, 1936; reviewed by Hörstadius, 1973, pp. 96-103). Wilson (1925; Fig. 515) interpreted this result as merely a consequence of the primordial animalvegetal stratification of morphogenetic factors in the egg; since the first two cleavage planes lie in the animalvegetal axis, all four blastomeres should contain all of the necessary factors distributed along the animalvegetal axis, and hence their capacity for normal development. But this was before the experiments of Hörstadius and his school, which showed that animal cap cells alone, if supplied on their vegetal surface with a few micromeres, could also reconstruct a whole embryo, including the gut, which normally derives exclusively from the vegetal cells missing in this chimeric construct. So also can complete embryos be regulatively reconstructed from combinations of other horizontal tiers of cells, including embryos without micromeres, or LiCl-treated animal cap cells (reviewed by Hörstadius, 1973 , pp. 47-69, 107-111). In a recent article, I reinterpreted these classical observations in terms of the conditional specification system discussed here, in which development is mediated by inductiveligand receptor interactions that are predicted to occur between adjacent cells along the canonically positioned, invariant planes of cleavage (Davidson, 1989). As shown there, the extensive regulative reconstructions of which the sea urchin embryo is capable can thus be explained, in principle, by the interactive mechanism illustrated in the simplified cartoon shown in Fig. 2 of this paper. The specific presumptions are that the vegetal-most skeletogenic mesenchyme cells (i.e. the micromere lineage) are autonomously specified; and that the remaining specifications along the animalvegetal axis occur conditionally, stepwise. Thus the micromeres induce gut histospecific gene batteries in whatever cells they are adjacent to, in normal or chimeric embryos, and these in turn present ligands that induce (or permit) ectoderm expression in the cells overlying them, etc. The oral-aboral axis is generated by another superimposed conditional specification process, in which the initial radially symmetric egg cytoplasm is polarized (Czihak, 1963), and through interactions occurring between 2 nd and 6th cleavage there arise along this axis two sets of lineages that from late cleavage on display different patterns of histospecific gene expression (Davidson, 1989). Thus the aboral ectoderm becomes a squamous epithelial larval body wall characterized by expression of specifically expressed cytoskeletal and other genes, while the oral ectoderm, including the neurogenic territories of the late embryo, carries out a more complex morphogen- etic development, including the construction of the mouth; and the ciliary bands that arise at the interface of the oral and aboral territories. This interpretation permits specific predictions regarding the spatial location in the embryo of histospecific regulatory factors, both active and inactive, in normal as well as regulative development (see Fig. 2; Davidson, 1989).

We now know something about the molecular basis of spatial expression of a charter member of the aboral ectoderm gene battery, and it is interesting to consider how Driesch's experiment would perturb this regulatory system. The CyIIIa cytoskeletal actin gene is expressed only in aboral ectoderm, and its spatial activation is controlled negatively (reviewed by Davidson, 1989). There are two distinct sites in the regulatory region of this gene that react with DNA-binding factors that are specifically responsible for confining expression of the gene to aboral ectoderm. If these interactions are interfered with, expression of fusion constructs controlled by this regulatory domain now occurs ectopically, i.e. in gut, mesenchyme cells and oral ectoderm. Factors interacting at one of these sites, called the P3A factors, have been cloned and characterized (C. Höög, F. Calzone, unpublished data). Since any radial sector of animal pole egg cytoplasm may constitute a portion of either the oral or aboral ectoderm regulatory domains, a reasonable hypothesis is that a form of P3A factor is in the beginning radially distributed. In the normal egg, the polarization that initially specifies the oral-aboral axis must at the future aboral end result in inactivation of the repressive P3A factor in the quadrant of cytoplasm normally inherited by aboral ectoderm founder cells. For example, the activity of a protein kinase could be affected by this cytoskeletal polarization, and either the P3A factor or a molecule binding to it changed in functional competence as a result. In the Driesch experiment, the $\mathrm{O} / \mathrm{Abo}$ axis has to be reestablished all over again in the apposed blastomeres formed in successive divisions in each of the four blastomere isolates. That the Driesch experiment works thus confirms that the maternal negative regulatory factors controlling aboral ectoderm gene expression must indeed be radially distributed in the egg, and that their activity or inactivity must be easily and reversibly alterable. These are of course the features that the embryo relies upon for second axis formation in normal development.

\section{What are the regulatory principles?}

To obtain an insight into the internal structures of the diverse forms of embryogenesis considered, their observable characteristics were in this article first resolved into a set of classificatory processes; these were then interpreted in terms of a simple regulatory scheme for embryonic cell specification in which the major elements are transcription factors for histospecific genes, and blastomere ligands, receptors and signal transduction systems. Applied to various experimental 
observations, this scheme is useful for discovering what might be the key features of the regulatory architectures underlying different forms of embryonic development. Since the basic objective is to understand what makes the various spatial domains of the early embryo functionally diverse, in terms of cell structure, behavior and synthetic activity, the problem of regulatory architecture has to be considered in particular at the level of the histospecific structural genes that endow the embryo with its specific regional functions. We cannot achieve this end by concerning ourselves entirely with the interactions of regulatory genes, while waving our hands at that which they ultimately regulate.

If by regulatory architecture we mean the specific designs of the mechanisms utilized to establish differentially functioning spatial territories in various embryos, the plan of the regulatory interactions required, the levels of hierarchy amongst regulatory genes and so forth, then it is clear that the architectures underlying cell specification in the various embryonic forms are themselves very diverse. This follows as an obvious implication of the different usages of primordial spatial organization, of cell interaction and of the different temporal orders in which occur the processes of histospecific and regional specification in the various forms considered. The Drosophila embryo illustrates the point, not only because we have more direct knowledge of some of the reaches of its regulatory architecture, but mainly because of its unusual developmental features. These begin with the primordially biaxial egg and the syncytial embryo, two unique features that create the constraints met by a special genetic regulatory system that accomplishes domainial or regional specification initially without any cell interaction. That the Drosophila egg is so atypical is perhaps no surprise. It alone amongst those listed in Table 1 is the product of a syncytial oogenetic complex including fifteen stereospecific, polyploid nurse cells, containing in the aggregate almost 15000 haploid genomes (Hammond and Laird, 1985), the whole of which is encased in a follicular epithelium, which is regionally diversified in terms of gene expression (Cooley et al. 1988), and is itself spatially organized according to the same two axes as are imposed on the egg within (i.e. anteriorposterior and dorsal-ventral). Oogenesis of all of the other eggs considered in Table 1 either occurs within follicular layers that at most bear a monaxial orientation (e.g. in Xenopus) or for the major part of the process of oogenesis the oocytes are without any closely applied follicle cells (e.g. C. elegans or sea urchin).

Given that the naive belief that there is some general regulatory architecture that will explain all forms of embryonic development is unsupportable, it is the particular regulatory architecture underlying the embryonic process in each animal taxon that is the key to understanding how its embryos achieve development. Nonetheless, if not the overall architectural plans, we are entitled to ask what are the highest level regulatory units that could be universal and common to all forms of embryonic specification. This problem is briefly considered in the following.

\section{Kinds of regulatory genes}

In addition to histospecific structural genes and to structural genes that are expressed in many different cell types (whether inducibly or constitutively), there may be several functional classes of regulatory genes, or at least of regulatory gene functions. Regulatory genes are here narrowly defined as genes that produce DNAbinding proteins, which affect gene expression, or genes that produce proteins, which directly interact with such DNA-binding proteins, altering their regulatory activity. First, all embryos clearly need regulatory genes that control and coordinate the expression of histospecific batteries of structural genes, i.e. muscle-specific genes, ectoderm-specific genes, gut-specific genes, neuroblast genes, etc. Second, it may be predicted that embryos utilize regulatory genes whose function it is to operate local morphogenetic programs. By this is meant genes that control spatial processes that determine detailed spacing, positioning and pattern of local features such as hair, bristles, feathers, nerves, spicules, bone rudiments, etc.; genes that control local morphogenetic responses to diffusible morphogen gradients, e.g. in vertebrate limb morphogenesis; genes that determine tubular morphological differentiation, as in many internal vertebrate organ systems, and so forth. Third, much recent study has been devoted to genes that apparently serve as regional identifiers. Many though not all of these (vide the gap genes of Drosophila) are homeobox genes (McGinnis et al. 1984; Gehring, 1987). Within the large regions of the organisms in which such genes are active, e.g. the head or posterior sections of an early embryo, or a major region of the CNS, or particular organ system anlage in later embryos, many different histospecific batteries of genes must be expressed, but the same histospecific gene batteries are often or usually expressed in several other regions as well. For example, muscle occurs in a number of different body regions. Regional identifier genes are thus not in themselves necessary and sufficient, or unique, histospecific gene battery regulators. Nor do they uniquely specify the spatial distribution of other downstream regional identifier gene products. The activity of these always depends on the distribution of the products of multiple, previously active regional identifier genes.

In some embryos, as we have seen, histospecification precedes regional identification, while in others it follows regional identification. However, each such region of the organism can be said to be the locus of action of a unique set of local morphogenetic programs, while individual programs of this kind are also likely to be called upon in several different regions; e.g. hair pattern morphogenetic programs are utilized in different regions of the mammalian body.

\section{The 'smart' histospecific structural gene}

The degree of hierarchy necessary in a developmental regulatory architecture depends to a large extent on the regulative capacities of the individual histospecific structural genes that are its ultimate effectors. One of the most interesting principles emerging from analyses 
of the regulatory molecular biology of histospecific genes is that their cis regulatory systems have many more elements, and are far more complex, than might have been expected. These are 'smart' control systems that integrate diverse informational inputs. To consider two examples very briefly, the chicken $\beta$-globin gene has about fifteen sites of DNA-protein interaction, some of which bind temporal regulatory factors early in development, some erythrocyte-specific factors, some amplitude modifiers, some negative regulators apparently used later in development, etc. (Emerson et al. 1985; 1987; Lewis et al. 1988; Evans et al. 1988); and similarly, the CyIIIa cytoskeletal actin gene of $S$. purpuratus, which is expressed specifically in the embryonic aboral ectoderm, has about twenty sites of regulatory DNA-protein interaction. Again, some of these probably control lineage-specific spatial expression, some developmental temporal activation, some amplitude, etc. (reviewed by Davidson, 1989). A regulatory system of this sort is shown in the heuristic cartoon in Fig. 3A; the import is that many different signals conveying information with respect to cell type, developmental stage, local morphogenetic program, cell cycle, etc. are combinatorily integrated so as to be transduced into a single scalar function, transcription rate. The smart histospecific structural gene may be one of the universal features on which embryonic and other developmental processes depend.

In some organisms, relatively non-hierarchical systems built entirely of smart histospecific genes and their regulators could be sufficient to account for the initial set of embryonic cell specifications. Examples might be the sea urchin, the $C$. elegans, the gastropod or the ascidian embryos. In these embryos, the cell specification processes produce a small number of territories each of which are composed of a nonoverlapping set of cell lineages. Within each territory, a defined, unique set of histospecific gene batteries and of local morphogenetic programs is expressed. For example, Fig. 3B shows the Strongylocentrotus blastula divided into four territories by the cleavage stage specification processes discussed earlier (Davidson, 1989). Neurogenesis occurs within the oral ectoderm territory; the internal organs and muscle derive wholly from the $\mathrm{Veg}_{2}$ territory; the skeleton entirely from the skeletogenic mesenchyme territory consisting of micromere progeny; etc. Additional upper level hierarchy regulatory functions, e.g. regional identification functions, would not seem to be required, because there are no sets of histospecific or morphogenetic processes that are not already separated from one another in the initial territorial cell lineage segregations. It may be significant that in this organism, although there is as usual a collection of homeobox genes in the genome (Dolecki et al. 1986), it appears that none is expressed very early in development (Dolecki et al. 1988; Dolecki and Humphreys, 1988; Wang et al. 1990). The initial regional expression of one of the homeobox genes, $T$ gHbox 1 , occurs in the aboral ectoderm, long after the specification of the eleven lineages that constitute this territory (Angerer et al. 1989). Two others (TgHbox-4 and -5) are represented by transcripts that first occur at blastula or gastrula stage, i.e., clearly following the specification and commitment of the cells of the ectoderm and skeletogenic territories, and three others are expressed significantly only in adult tissues. The significance of sea urchin homeobox gene expression thus most likely lies in late or postembryonic developmental process, perhaps organogenesis. In this embryo, and others like it, the initial spatial diversifications can likely be accounted for by processes of conditional and autonomous specification that directly affect batteries of smart histospecific structural genes, and thus regional identification processes are less likely to be required.

\section{Regulatory hierarchies}

In Fig. $3 \mathrm{C}$ is a cartoon intended to communicate the nature of the regulatory problem presented in embryos in which the major regions of the body plan are first defined by regional identifier functions, followed by histospecification. Within these regions (shaded), there operate partially overlapping sets of morphogenetic programs (figured by different symbols) and largely overlapping sets of histospecific gene batteries (not shown). Regional identifiers may operate negatively, preventing the exercise of given morphogenetic programs within the regions in which they are expressed. An example might be the Xhox3 gene of Xenopus, normally expressed in the posterior regions of the Xenopus neurula (Ruiz i Altaba and Melton, 1989b). When ectopic expression is induced in the head region, the result is to suppress anterior morphogenesis, rather than to induce posterior morphogenesis in the head. Or the result of ectopic expression of such genes may be to permit in new locations the execution of morphogenetic programs that normally are allowed to operate only in the original domains of expression of the identifier function. Examples might include the result of ectopic expression of the Antennapedia gene on antenna imaginal disc morphogenesis (Schneuwly et al. 1987), or of ectopic bicoid expression (Frohnhöfer and NüssleinVolhard, 1986; Driever et al. 1989; Struhl et al. 1989) in Drosophila, and of gain-of-function homeotic transformations in general. The usual view of regional identifier genetic function, for example along the anterior-posterior axis of Drosophila, is a deeply hierarchical one. Thus the networks of interactions among these genes, by which they define and refine their domains of expression along this axis (e.g. see reviews of Akam, 1987; Scott and Carroll, 1987; Levine and Hoey, 1988; Ingham, 1988) are customarily regarded as interactions occurring at the upper hierarchical level. That is, the hierarchical interpretation is that the regional identifier genes (i.e. selector genes, homeotic genes, homeobox genes expressed regionally during development, etc.) produce regulatory factors that determine the expression of lower regulatory genes controlling the local morphogenetic programs, while the factors made by the latter control still lower regulatory genes that in turn produce histospecific battery regulators, etc. However, it is yet impossible to discern whether all these layers of regulatory hierarchy 

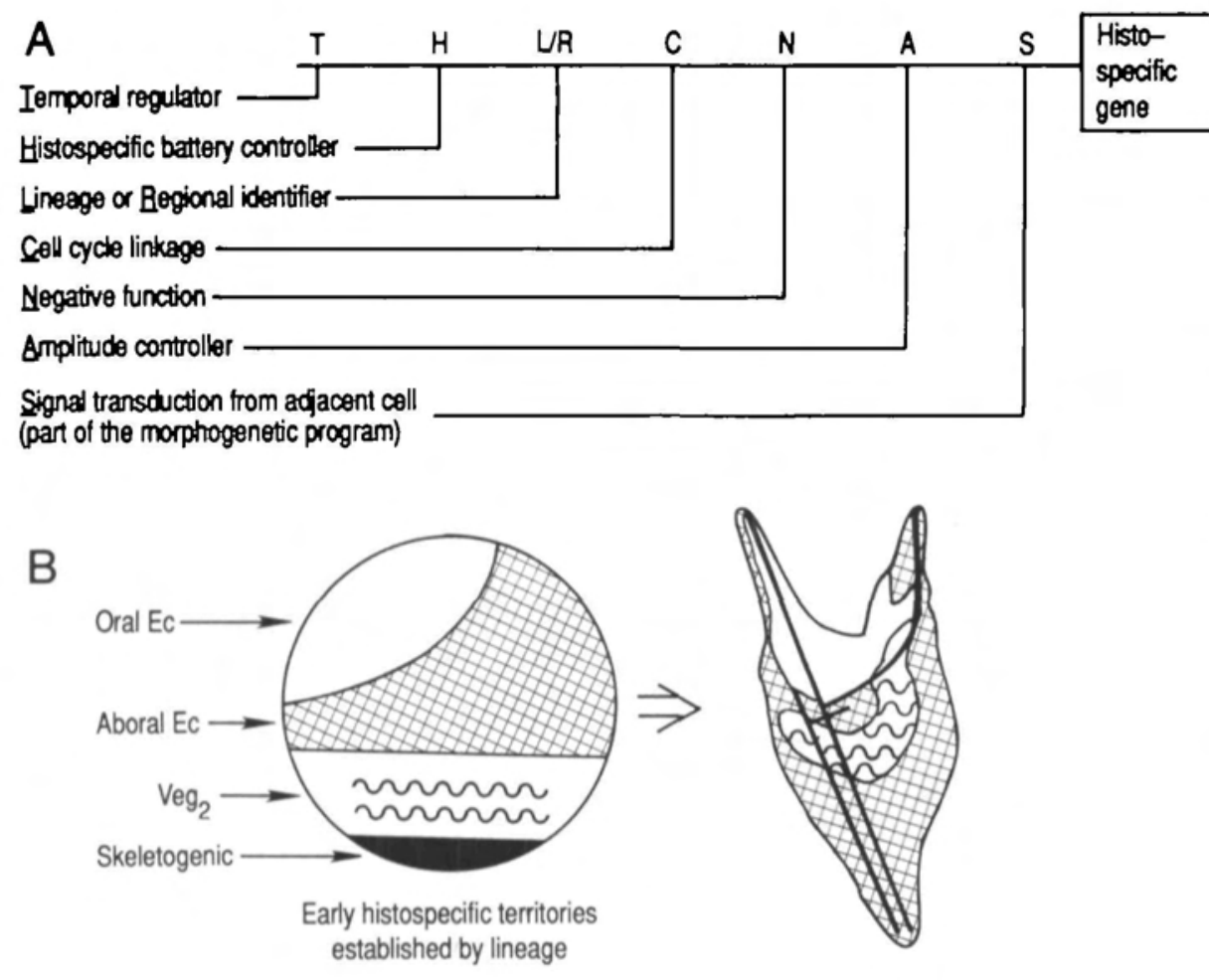

C

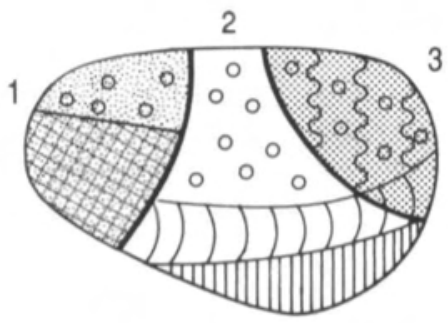

Three regions of an abstract embryo expressing different morphogenetic program sets
Fig. 3. Aspects of regulatory architecture relevant to early development. (A) The 'smart' histospecific structural gene: A nonhierarchical model for developmental control of gene expression. The regulatory system behaves like a logic chip and integrates the state of all of the different inputs. Each input (i.e. species of active factor interaction) itself organizes a set of genes that share its binding site. Thus there will be sets of genes that respond to $C$, the cell cycle operator; a different set that responds to $\mathrm{T}$, the temporal operator; expression of which is modulated by $\mathrm{A}$, the enhancer factor; etc. $\mathrm{H}$ is a factor that activates a set of genes that is differentially required for the nominal histospecific cell type of the example. The set of genes responding to $\mathrm{H}$ has been classically referred to as a 'gene battery', though some genes of this set may in fact respond to different additional signals. $\mathrm{S}$ and $\mathrm{N}$ could constitute the functions that are required for morphogenetic control. For instance, $\mathrm{S}$ could respond to a diffusible morphogen gradient, and $\mathrm{N}$ a 'lateral inhibition' factor that prevents two adjacent cells from expressing a gene that is utilized periodically in space. An important feature of this model is the role envisioned for $(\mathrm{L} / \mathrm{R})$, the regional identifier factor. Interaction at this site would be necessary for the system to operate, but not sufficient, i.e. the

(L/R) interaction need have no biochemical significance from that of the other interactions. However, a different possibility that could also be included in the concept portrayed in this Fig. is that the (L/R) interaction might differ from the others shown in that it could potentiate the other interactions. For example, this interaction might alter local chromatin structure so as to facilitate or permit the other interactions shown (or prevent them). In either case ectopic expression of $L / R$ might in itself convert the histospecific gene from an inactive to expressed state if the gene is in a domain that possesses the other necessary regulators, but in which this gene is normally not expressed. (B) The sea urchin embryo: A system that does not need early regional identifier functions because the initial lineage specifications are histospecifications. Each of the territories shown on the left are separate as a result of cleavage-stage specification, so that given histospecific gene batteries are only used within that territory: open, oral ectoderm; hatched, aboral ectoderm; wavy line, gut and definitive mesenchyme (veg ${ }_{2}$ territory); solid, skeletogenic mesenchyme (according to Davidson, 1989). A fifth territory, which is composed of the small micromeres at the vegetal pole of the egg, has been omitted for simplicity. Within each territory unique morphogenetic programs must be activated. (C) An abstract embryo in which histospecification (not shown) occurs long after cleavage, and is preceded by regional identification. The different symbolic figures within the regions 1,2 and 3 represent different morphogenetic programs, each of which may utilize histospecific gene batteries also used by other morphogenetic programs (and in other regions). However, each regional identifier specifies a unique set of morphological programs (right).

indeed exist, though the types of regulatory gene involved do, and the amount of hierarchy might be greatly exaggerated in such concepts. Thus, for example, a smart histospecific gene regulation system might be capable of directly accepting a factor produced by a regional identifier gene and factors produced by local morphogenesis control genes, as elements required to be bound (or not bound) in order for function to occur, as in Fig. 3A.

In conclusion, the smart histospecific structural gene is probably among the universal underlying features that enables development. In different contexts, this integrating regulatory unit can account for a great variety of sophisticated and diverse developmental 
phenomena. The various ways that the several classes of regulatory genes are utilized, together with the critical modulations of their function effected by intercellular signal transduction events, are the sources of the variety in regulatory architecture that underlies the many different modes of embryogenesis that we see.

\section{Conclusions}

So how do embryos work? Or, the question to which we have come, what regulatory structures are required to explain the appearance of differential spatial patterns of histospecific gene expression in embryos of diverse taxa? The answer is clearly different for different embryos, but there are certain sets of strategies that groups of phylogenetically unrelated animals share. Embryos in which maternal cytoarchitectural spatial organization is utilized to set up regulatory domains that coincide with canonical cleavage planes constitute one important group, including many invertebrate embryos, both deuterostome and protostome. Thus autonomous specification of certain lineage founder cells, with more or less extensive conditional specification of the remainder of the founder cells, is the basic mechanism in nematode, echinoderm, ascidian and molluscan embryos, among those considered here. For these forms, the problem of explaining the initial mechanisms by which given cell types arise in the appropriate regions of the embryo can probably be solved directly by molecular definition of three aspects: the cis regulatory apparatus that animates the smart histospecific structural genes whose expression defines the initial cell types; the origin and spatial disposition, with respect to the founder cell domains, of the conditionally activated or localized regulatory factors that interact with these apparatuses; and the relevant cytoskeletal structures built into the egg during oogenesis. It seems unlikely that additional layers of regulatory hierarchy will be required until later, in organogenesis. In Drosophila, many of these same elements of mechanism also evidently operate, but the variable syncytial nature of the cleavage process imposes a requirement for complex, prior regulatory functions that regionally and progressively specify the embryonic cell nuclei. Vertebrate embryos also must require regional identity functions, but for a wholly different reason. Some of these embryos, e.g. fish, bird and mammalian embryos, have reversed the order of events seen in their lower deuterostome relatives. These embryos generate large numbers of cells in which histospecification follows cleavage, and is separated from it by extensive cell migration. Thus these embryos cannot utilize spatial relations derived from cleavage, i.e. from the maternal cytoarchitecture, to accomplish most of their histospecification and, following migration, they must first identify multicellular regulatory domains within which the downstream regulatory programs will operate. We shall have to understand how these vertebrate regional identification functions interact with one another to set up the relevant spatial domains, and then how con- ditional specification occurs within them, so as to account for the ultimate patterns of histospecific gene expression. In this light, the frog presents an interesting hybrid process, because this vertebrate embryo does rely in part on histospecification occurring by interaction between cleavage blastomeres, and on maternal cytoarchitectural structure. It is clear that a casualty of these arguments is the 19th century concept that early development must be an evolutionarily conserved process. We see that during evolution the regulatory genetic elements controlling embryogenesis have been reassembled in many different combinations.

Research from the laboratory was supported by an NIH grant (HD-05753), and the development of some of the ideas was initiated with a project supported by a Lucille P. Markey Trust Grant in Developmental Biology. I am deeply grateful for the perspicacity, depth of knowledge and great generosity of the many reviewers who contributed so much of their time in criticizing drafts of the manuscript, and whose encouragement and insights have affected it in so many ways. These are Drs James W. Posakony of UC San Diego, Michael Levine of Columbia University, Corey Goodman of UC Berkeley, Richard Whittaker of MBL, Scott Fraser of UC Irvine, Dennis Powers of Hopkins Marine Station, and Barbara Evans, Andrew Cameron, Ellen Rothenberg, Paul Sternberg and Roy Britten at Caltech.

\section{References}

Akam, M. (1987). The molecular basis for metameric pattern in the Drosophila embryo. Development 101, 1-22.

Albertson, D. G. (1984). Formation of the first cleavage spindle in nematode embryos. Devl Biol. 101, 61-72.

ANDERSON, K. AND Nússlein-Volhard, C. (1984). Information for the dorsal-ventral pattern of the Drosophila embryos is stored as maternal mRNA. Nature, Lond. 311, 223-227.

Angerer, L. M., Dolecki, G. J., Gagnon, M., Lum, R., Wang, G., YANG, Q., Humphreys, T. ANd ANGerer, R. C. (1989). Progressively restricted expression of a homeobox gene within the aboral ectoderm of developing sea urchin embryos. Genes \& Dev. 3, 370-383.

ARnolds, W. J. A., Van den Biggelaar, J. A. M. and Verdonk, N. H. (1983). Spatial aspects of cell interactions involved in the determination of dorsoventral polarity in equally cleaving gastropods and regulative abilities of their embryos, as studied by micromere deletions in Lymnaea and Patella. Wilhelm Roux' Arch. devl Biol. 192, 75-85.

Atchison, M. L. and Perry, R. P. (1987). The role of the א enhancer and its binding factor NF-kB in the developmental regulation of $\kappa$ gene transcription. Cell $\mathbf{4 8}, 121-128$.

Austin, J. AND Kimble, J. (1987). glp-1 is required in the germ line for regulation of the decision between mitosis and meiosis in $C$. elegans. Cell 51, 589-599.

AustiN, J. AND Kimble, J. (1989). Transcript analysis of glp-1 and lin-12, homologous genes required for cell interactions during development of $C$. elegans. Cell 58, 565-571.

Baeurrte, P. A. and Baltimore, D. (1988). I B: A specific inhibitor of the NF- $\mathrm{AB}$ transcription factor. Science 242, 540-546.

Ballard, W. W. (1973). A new fate map for Salmo gairdneri. J. exp. Zool. 184, 49-74.

Bates, W. R. AND JeFFERY, W. R. (1988). Polarization of coplasmic segregation and dorsal-ventral axis determination in ascidian embryos. Devl Biol. 130, 98-107.

Beddington, R. (1983). The origin of the foetal tissues during gastrulation in the rodent. In Development in Mammals vol. 5 (ed. M. H. Johnson), pp. 1-32, Amsterdam: Elsevier Science Publishers.

Beer, J., Technau, G. M. and Campos-Ortega, J. A. (1987). 
Lineage analysis of transplanted individual cells in embryos of Drosophila melanogaster. Wilhelm Roux' Arch. devl Biol. 196, 222-230.

Berleth, T., Burri, M., Thoma, G., Bopp, D., Richstein, S. Frigerio, G., Noll, M. and Nusslein-Volmard, C. (1988). The role of localization of bicoid RNA in organizing the anterior pattern of the Drosophila embryo. EMBO J. 7, 1749-1756.

BLACK, S. D. AND VinCENT, J.-P. (1988). The first cleavage plane and the embryonic axis are determined by separate mechanisms in Xenopus laevis. Devl Biol. 128, 65-71.

BoverI, T. (1907). Zellenstudien VI: Die Entwicklung dispermer Seeigeleier. Ein Beitrag zur Befruchtungslehre und zur Theorie des Kernes. Jena. Zeitschr. Naturw. 43, 1-292.

Braun, T., Buschhausen-Denker, G., Bober, E., Tannich, E. AND ARNOLD, H. H. (1989). A novel human muscle factor related to but distinct from MyoD1 induces myogenic conversion in 10T1/2 fibroblasts. EMBO J. 8, 701-709.

BusA, W. B. AND GimLich, R. L. (1989). Lithium-induced teratogenesis in frog embryos prevented by a polyphosphoinositide cycle intermediate or a diacyclglycerol analog. Devl Biol. 132, 315-324.

Cabrera, C. V., Alonso, M. C., Johnston, P., Phillips, R. G. and Lawrence, P. A. (1987). Phenocopies induced with antisense RNA identify the wingless gene. Cell 50, 659-663.

Cameron, R. A., Fraser, S. E., Britten, R. J. and Davidson, E. $H$. (1989). The oral-aboral axis of a sea urchin embryo is specified by first cleavage. Development 106, 641-647.

Casanova, J. AND Struhl, G. (1990). Localized surface activity of torso, a receptor tyrosine kinase, specifies terminal body pattern in Drosophila. Genes \& Dev. (in press).

Cascio, S. And Gurdon, J. B. (1987). The initiation of new gene transcription during $X$ enopus gastrulation requires immediately preceding protein synthesis. Development 100, 297-305.

Clavert, J. (1960a). Déterminisme de la symétrie bilatérale chez les oiseaux. II. Influence de la "présentation" de l'oeuf dans l'utérus sur l'orientation de l'embryon. Arch. Anat. Micro. Morph. exp. 49, 1-22.

Clavert, J. (1960b). Déterminisme de la symétrie bilatérale chez les oiseaux. III. Influence de la position de l'axe de l'oeuf dans l'utérus sur l'orientation de l'embryon. Arch. Anat. Micro. Morph. Exp. 49, 207-227.

Clement, A. C. (1952). Experimental studies on germinal localization in llyanassa. I. The role of the polar lobe in determination of the cleavage pattern and its influence in later development. J. exp. Zool. 121, 593-625.

Clement, A. C. (1962). Development of llyanassa following removal of the $\mathrm{D}$ macromere at successive cleavage stages. $J$. exp. Zool. 149, 193-216.

Cockroft, D. L. AND GARDNer, R. L. (1987). Clonal analysis of the developmental potential of 6 th and 7 th day visceral endoderm cells in the mouse. Development 101,143-155.

ConkLIN, E. G. (1905). The organization and cell lineage of the ascidian egg. J. Acad. natn. Sci. Phila. 13, 1-119.

Cooley, L., Kelley, R. and Spradling, A. (1988). Insertional mutagenesis of the Drosophila genome with single $\mathrm{P}$ elements. Science 239, 1121-1128.

Cowan, A. E. and McIntosh, J. R. (1985). Mapping the distribution of differentiation potential for intestine, muscle, and hypodermis during early development in Caenorhabditis elegans. Cell 41, 923-932.

Crabtree, G. R. (1989). Contingent genetic regulatory events in T lymphocyte activation. Science 243, 355-361.

Crowther, R. J. AND WhitTaker, J. R. (1983). Developmental autonomy of muscle fine structure in muscle lineage cells of ascidian embryos. Devl Biol. 96, 1-10.

Crowther, R. J. AND Whittaker, J. R. (1984). Differentiation of histospecific ultrastructural features in cells of cleavage-arrested early ascidian embryos. Wilhelm Roux' Arch. devl Biol. 194, 87-98.

Crowther, R. J. and WhrtTaker, J. R. (1986). Differentiation without cleavage: Multiple cytospecific ultrastructural expressions in individual one-celled ascidian embryos. Devl Biol. 117, $114-116$

Curran, T. (1988). The fos oncogene. In The Oncogene Handbook (ed. E. P. Reddy, A. M. Skalka and T. Curran), pp. 307-325. Amsterdam: Elsevier Science Publishers.

CzIHAK, G. (1963). Entwicklungsphysiologische Untersuchungen an Echiniden (Verteilung und Bedeutung der Cytochromoxydase). Wilhelm Roux' Arch. EntwMech. Org. 154, 272-292.

Dale, L. And Slack, J. M. W. (1987). Fate map for the 32-cell stage of Xenopus laevis. Development $99,527-551$

Danilchik, M. V. AND BLACK, S. D. (1988). The first cleavage plane and the embryonic axis are determined by separate mechanisms in Xenopus laevis. I. Independence in undisturbed embryos. Devl Biol. 128, 58-64.

Danilchik, M. V. and GerharT, J. C. (1987). Differentiation of the animal-vegetal axis in Xenopus laevis oocytes. Devl Biol. 122 , 101-112.

Davidson, E. H. (1968). Gene Activity in Early Development. New York: Academic Press.

Davidson, E. H. (1986). Gene Activity in Early Development, Third Edition. Orlando, Florida: Academic Press.

Davidson, E. H. (1989). Lineage-specific gene expresion and the regulative capacities of the sea urchin embryo: a proposed mechanism. Development 105, 421-445.

Davidson, E. H. And Brttien, R. J. (1971). Note on the control of gene expression during development. J. theor. Biol. 32, 123-130.

Davidson, E. H., Haslett, G. W., Finney, R. J., Allfrey, V. G AND MirsKY, A. E. (1965). Evidence for prelocalization of cytoplasmic factors affecting gene activation in early embryogenesis. Proc. natn. Acad. Sci. U.S.A. 54, 696-704.

Delegeane, A. M., Ferland, L. H. and Mellon, P. L. (1987) Tissue-specific enhancer of the human glycoprotein hormone $\alpha$ subunit gene: Dependence on cyclic AMP-inducible elements. Mol. Cell. Biol. 7, 3994-4002.

Deno, T., Nishida, H. and Satoh, N. (1985). Histospecific acrtylcholinesterase development in quarter ascidian embryos derived from each blastomere pair of the eight-cell stage. Biol. Bull. mar. Biol. Lab., Woods Hole 168, 239-248.

Deno, T. And Satoh, N. (1984). Studies on the cytoplasmic determinant for muscle cell differentiation in ascidian embryos: An attempt at transplantation of the myoplasm. Develop. Growth and Differ. 26, 43-48.

Doe, C. Q., Hiromi, Y., Gehring, W. J. and Goodman, C. S. (1988a). Expression and function of the segmentation gene fushi tarazu during Drosophila neurogenesis. Science 239, 170-175.

Doe, C. Q., Smouse, D. And Goodman, C. S. (1988b). Control of neuronal fate by the Drosophila segmentation gene even-skipped. Narure, Lond. 334, 376-378.

Dolecki, G. J. AND HumphreYs, T. (1988). An engrailed class homeo box gene in sea urchins. Gene 64, 21-31.

Dolecki, G. J., WANG, G. ANd HumphreYs, T. (1988). Stage- and tissue-specific expression of two homeo box genes in sea urchin embryos and adults. Nucleic Acids Res. 16, 11 543-11 558.

Dolecki, G. J., Wannakrairoj, S., Lum, R., Wang, G., Riley, H. D., Carlos, R., WanG, A. And Humphreys, T. (1986). Stagespecific expression of a homeobox-containing gene in the nonsegmented sea urchin embryo. EMBO J. 5, 925-930.

DrIesCH, H. (1891). Entwicklungsmechanische Studien. Zeitschrift fur Wussenschaftiche Zoologie 53, 160-183.

Driesch, H. (1900). Die isolirten Blastomeren des Echinidenkeimes. Wilhelm Roux' Arch. EntwMech. Org. 10 $361-410$.

Driever, W. and Nusslein-Volmard, C. (1988a). The bicoid protein determines position in the Drosophila embryo in a concentration-dependent manner. Cell 54, 95-104.

Driever, W. AND NÚsslein-Volhard, C. (1988 b). A gradient of bicoid protein in Drosophila embryos. Cell 54, 83-93.

Driever, W. and Nusslein-Volmard, C. (1989). The bicoid protein is a positive regulator of hunchback transcription in the early Drosophila embryo. Nature, Lond. 337, 138-143.

Driever, W., Thoma, G. and NÚsslein-Volhard, C. (1989). Determination of spatial domains of zygotic gene expression in the Drosophila embryo by the affinity of binding sites for the bicoid morphogen. Nature, Lond. 340, 363-367.

Durston, A. J., Timmermans, J. P. M., Hage, W. J., Hendriks, H. F. J., De VRies, M. J., Heideveld, M. ANd NieuwKoop, P. D. (1989). Retinoic acid causes an anteroposterior 
transformation in the developing central nervous system. Nature, Lond. 340, 140-144.

Edgar, L. G. ANd McGhee, J. D. (1986). Embryonic expression of a gut-specific esterase in Caenorhabditis elegans. Devl Biol. 114, 109-118.

Edwards, M. K. S. and McBurney, M. W. (1983). The concentration of retinoic acid determines the differentiated cell types formed by a teratocarcinoma cell line. Devl Biol. 98, 187-191.

Emerson, B. M., Lewis, C. D. And Felsenfeld, G. (1985). Interaction of specific nuclear factors with the nucleasehypersensitive region of the chicken adult $\beta$-globin gene: Nature of the binding domain. Cell 41, 21-30.

Emerson, B. M., Nickol, J. M., Jackson, P. D. and Felsenfeld, G. (1987). Analysis of the tissue-specific enhancer at the $3^{\prime}$ end of the chicken adult $\beta$-globin gene. Proc. natn. Acad. Sci. U.S.A. 84, 4786-4790.

Epstein, H. F., Miller III, D. M., Gossett, L. A. and Hecht, R. M. (1982). Immunological studies of myosin isoforms in nematode embryos. In Muscle Development (ed. M. Pearson and H. Epstein), pp. 7-14, Cold Spring Harbor, New York: Cold Spring Harbor Laboratory.

Evans, T., Rettman, M. and Felsenfeld, G. (1988). An erythrocyte-specific DNA-binding factor recognizes a regulatory sequence common to all chicken globin genes. Proc. natm. Acad. Sci. U.S.A. 85, 5976-5980.

EYAL-GILADI, H. (1969). Differentiation potencies of the young chick blastoderm as revealed by different manipulations. I. Folding experiments and position effects of the culture medium. J. Embryol. exp. Morph. 21, 177-192.

Fan, C.-M. and Maniatis, T. (1989). Two different virus-inducible elements are required for human $\beta$-IFN gene regulation. EMBO J. 6, 101-110.

FAN, C.-M. AND MaNiaTnS, T. (1990). A DNA binding protein containing two widely separated zinc finger motifs that recognize the same DNA sequence. Genes and Devl 4, 29-42.

Fisch, T. M., Prywes, R., Simon, M. C. And Roeder, R. G (1989). Multiple sequence elements in the $c$-fos promoter mediate induction by cAMP. Genes \& Dev. 3, 198-211.

FrEEMAN, G. (1977). The establishment of the oral-aboral axis in the ctenophore embryo. J. Embryol. exp. Morph. 42, 237-260.

FreEman, G. (1979). The multiple roles which cell division can play in the localization of developmental potential. In Determinants of Spatial Organization (ed. S. Subtelny and I. R. Konigsberg), pp. 53-76. New York: Academic Press.

Frohnhofer, H. G. ANd NUSSlein-Volhard, C. (1986). Organization of anterior pattern in the Drosophila embryo by the maternal gene bicoid. Nature, Lond. 324, 120-125.

Gardner, R. L., Lyon, M. F., Evans, E. P. and Burtenshaw, M. D. (1985). Clonal analysis of X-chromosome inactivation and the origin of the germ line in the mouse embryo. J. Embryol. exp. Morph. 88, 349-363.

GAUL, U. AND JäCKLE, H. (1987). Pole region-dependent repression of the Drosophla gap gene Krilppel by maternal gene products. Cell 51, 549-555.

GeHRiNG, W. J. (1987). Homeo boxes in the study of development. Science 236, 1245-1252.

Gerhart, J., Black, S. ANd Scharf, S. (1983). Cellular and pancellular organization of the amphibian embryo. In Modern Cell Biology. Spatial Organization of Eukaryotic Cells (ed. R. McIntosh), Vol. 2, pp. 483-507. New York: Alan R. Liss.

Giguere, V., Ong, E. S., Evans, R. M. and Tabin, C. J. (1989). Spatial and temporal espression of the retinoic acid receptor in the regenerating amphibian limb. Nature, Lond. 337, 566-569.

Gillespie, L. L., Paterno, G. D. and Slack, J. M. W. (1989). Analysis of competence: Receptors for fibroblast growth factor in early Xenopus embryos. Development 106, 203-208.

Gimlich, R. L. AND Gerhart, J. C. (1984). Early cellular interactions promote embryonic axis formation in Xenopus laevis. Devl Biol. 104, 117-130.

Goodbourn, S. And Maniatis, T. (1988). Overlapping positive and negative regulatory domains of the human $\beta$-interferon gene. Proc, natn. Acad. Sci. U.S.A. 85, 1447-1451.

Goto, T., Macdonald, P. And Maniatis, T. (1989). Early and late periodic patterns of even skipped expression are controlled by distinct regulatory elements that respond to different spatial cues. Cell 57, 413-422.

GreENwALD, I. (1985). lin-12, a nematode homeotic gene, is homologous to a set of mammalian proteins that includes epidermal growth factor. Cell 43, 583-590.

Grunz, H., McKeehan, W. L., Knochel, W., Born, J. and Tiedmann, H. (1988). Induction of mesodermal tissues by acidic and basic heparin binding growth-factors. Cell Differ. 22, 183-190.

Guerrier, P., Van Den Biggelaar, J. A. M., Van Dongen, C. A. M. And Verdonk, N. H. (1978). Significance of the polar lobe for the determination of dorsoventral polarity in Dentalium vulgare (da Costa). Devl Biol. 63, 233-242.

Gurdon, J. B. (1987). Embryonic induction - molecular prospects. Development $99,285-306$.

Gurdon, J. B. (1989). The localization of an inductive response. Development 105, 27-33.

Gurdon, J. B., Fairman, S., Mohun, T. J. and Brennan, S. (1985). Activation of muscle-specific actin genes in Xenopus development by an induction between animal and vegetal cells of a blastula. Cell 41, 913-922.

Hammond, M. P. and Laird, C. D. (1985). Chromosome structure and DNA replication in nurse and follicle cells of Drosophila melanogaster. Chromosoma 91, 267-278.

Hashimoto, C., Hudson, K. L. and Anderson, K. V. (1988). The Toll gene of Drosophila, required for dorsal-ventral embryonic polarity, appears to encode a transmembrane protein. Cell 52, 269-279.

Heasman, J., Wylie, C. C., Hausen, P. and Smith, J. C. (1984). Fates and states of determination of single pole blastomeres of $X$. laevis. Cell 37, 185-194.

HOrSTADIUS, S. (1939). The mechanics of sea urchin development, studied by operative methods. Biol. Rev. Cambridge Phil. Soc. $14,132-179$.

HORSTADIUS, S. (1973). Experimental Embryology of Echinoderms. London and New York: Oxford Univ. Press (Clarendon).

Hórstadius, S. AND Wolsky, A. (1936). Studien über die Determination der Bilateralsymmetrie des jungen Seeigelkeimes. Willelm Roux Arch. EntwMech. Org. 135, 69-113.

Hoyos, B., Ballard, D. W., Bohnlein, E., SiekeVtTz, M. and GreENE, W. C. (1989). Kappa B-specific DNA binding proteins: role in the regulation of human interleukin-2 gene expression. Science 244, 457-460.

Illmensee, K. AND Mahowald, A. P. (1974). Transplantation of posterior polar plasm in Drosophila. Induction of germ cells at the anterior pole of the egg. Proc. natn. Acad. Sci. U.S.A. 71, 1016-1020.

Illmensee, K. And Mahowald, A. P. (1976). The autonomous function of germ plasm in a somatic region of the Drosophila egg. Expl Cell Res. 97, 127-140.

Ingham, P. W. (1988). The molecular genetics of embryonic pattern formation in Drosophila. Nature, Lond. 335, 25-34.

JACOBSON, M. AND XU, W.-L. (1989). States of determination of single cells transplanted between 512-cell Xenopus embryos. Devl Biol. 131, 119-125.

JefFERY, W. R. (1982). Calcium ionophore polarizes ooplasmic segregation in ascidian eggs. Science 216, 545-547.

JEFFERY, W. R. (1989). Requirement of cell division for muscle actin expression in the primary muscle cell lineage of ascidian embryos. Development 105, 75-84.

JefFries, R. P. S. (1986). The Ancestry of the Vertebrates. London: British Museum (Natural History).

Jones, E. A. AND WOOdLAND, H. R. (1986). Development of the ectoderm in Xenopus: Tissue specification and the role of cell association and division. Cell 44,345-355.

Jones, E. A. AND WoOdLand, H. R. (1987a). The development of animal cap cells in Xenopus: The effects of environment on the differentiation and the migration of grafted ectodermal cells. Development 101, 23-32.

Jones, E. A. AND Woodland, H. R. (1987b). The development of animal cap cells in Xenopus: A measure of the start of animal cap competence to form mesoderm. Development 101, 557-563. 
KAO, K. R. AND Elinson, R. P. (1989). Dorsalization of mesoderm induction by lithium. Devl Biol. 132, 81-90.

KaO, K. R., Masul, Y. ANd Elinson, R. P. (1986). Lithiuminduced respecification of pattern in Xenopus laevis embryos. Nature, Lond. 322, 371-374.

Keller, R. E. (1976). Vital dye mapping of the gastrula and neurula of Xenopus laevis. II. Prospective areas and morphogenetic movements of the deep layer. Devl Biol. 51, 118-137.

Kidd, S., Kelley, M. R. And Young, M. W. (1986). Sequence of the Notch locus of Drosophila: relationship of the encoded protein to mammalian clotting and growth factors. Mol. Cell. Biol. 6, 3094-3108.

Kimelman, D. AND Kirschner, M. (1987). Synergistic induction of mesoderm by FGF and TGF- $\beta$ and the identification of an mRNA coding for FGF in the early Xenopus embryo. Cell 51, $869-877$.

Kimmel, C. B. (1989). Geneties and early development of zebrafish. Trends Genet. 5, 283-288

Kimmel, C. B. AND LAw, R. D. (1985a). Cell lineage of zebrafish blastomeres. III. Clonal analyses of the blastula and gastrula stages. Devl Biol. 108, 94-101.

Kimmel, C. B. and Law, R. D. (1985b). Cell lineage of zebrafish blastomeres. I. Cleavage pattern and cytoplasmic bridges between cells. Devl Biol 108, 78-85.

Kimmel, C. B. and LAw, R. D. $(1985 c)$. Cell lineage of zebrafish blastomeres. II. formation of the yolk syncytial layer. Devl Biol $108,86-93$.

KImmel, C. B. AND WARGA, R. M. (1986). Tissue-specific cell lineages originate in the gastrula of the zebrafish. Science 231 , 365-368.

Kimmel, C. B. AND WARGA, R. M. (1987a). Indeterminate cell lineage of the zebrafish embryo. Devl Biol. 124, 269-280.

Kimmel, C. B. and Warga, R. M. (1987b). Cell lineages generating axial muscle in the zebrafish embryo. Nature, Lond. 327, 234-237

Kimmel, C. B. ANd WarGa, R. M. (1990). Cell movements during epiboly and gastrulation in zebrafish. Development Submitted for publication.

Kimmel, C. B., WarGa, R. M. And Schilling, T. F. (1990). A fate map for the zebrafish. Development Submitted for publication.

KLEIN, S. L. AND Moody, S. A. (1989). Lithium changes the ectodermal fate of individual frog blastomeres because it causes ectopic neural plate formation. Development 106, 599-610.

Klingler, M., Erdélyi, M., Szabad, J. and Nússlein-Volhard, C. (1988). Function of torso in determining the terminal anlagen of the Drosophila embryo. Nature, Lond. 335, 275-277.

Laufer, J. S., Bazzicalupo, P. ANd Wood, W. B. (1980). Segregation of developmental potential in early embryos of Caenorhabditis elegans. Cell 19, 569-577.

Lawson, K. A., Meneses, J. J. and Pedersen, R. A. (1986). Cell fate and cell lineage in the endoderm of the presomite mouse embryo, studied with an intracellular tracer. Devl Biol. 115, 325-339.

Levine, M. (1988). Molecular analysis of dorsal-ventral polarity in Drosophila. Cell 52, 785-786.

Levine, M. AND HoEy, T. (1988). Homeobox proteins as sequencespecific transcription factors. Cell 55, 537-540.

Lewis, C. D., Clark, S. P., Felsenfeld, G. and Gould, H. (1988). An erythrocyte-specific protein that binds to the poly $(\mathrm{dG})$ region of the chicken $\beta$-globin gene promoter. Genes \& Dev. 2, 863-873.

LoNo, W. L. (1983). The role of the yolk syncytial layer in determination of the plane of bilateral symmetry in the rainbow trout, Salmo gairdneri Richardson. J. exp. Zool. 228, 91-97.

Macdonald, P. M. ANd Struhl, G. (1986). A molecular gradient in early Drosophila embryos and its role in specifying the body pattern. Nature, Lond. 324, 537-546.

Macdonald, P. M. And Struhl, G. (1988). Cis-acting sequences responsible for anterior localization of bicoid mRNA in Drosophila embryos. Nature, Lond. 336, 595-598.

MADEN, M. (1985). Retinoids and the control of pattern in limb development and regeneration. Trends Genet. 1, 103-107.

Martinez-Arias, A., Baker, N. E. and Ingham, P. W. (1988).
Role of segment polarity genes in the definition and maintenance of cell states in the Drosophila embryo. Development 103, $157-170$

McGinnis, W., Levine, M., Hafen, E., Kuroiwa, A. And Gehring, W. (1984). A conserved DNA sequence in homeotic genes of the Drosophila Antennapedia and Bithorax complexes. Nature, Lond. 308, 428-433.

Melton, D. A. (1987). Translocation of a localized maternal mRNA to the vegetal pole of Xenopus oocytes. Nature, Lond. 328, 80-82.

Moody, S. (1987a). Fates of the blastomeres of the 32-cell stage Xenopus embryo. Devl Biol. 122, 300-319.

Moody, S. (1987b). Fates of the blastomeres of the 16-cell stage Xenopus embryo. Devl Biol. 119, 560-578.

Nakamura, O., Takasaki, H. and Mizohata, T. (1970). Differentiation during cleavage in Xenopus laevis. I. Acquisition of self-differentiation capacity of the dorsal marginal zone. Proc. Jpn. Acad. 46, 694-699.

Nishida, H. (1987). Cell lineage analysis in ascidian embryos by intracellular injection of a tracer enzyme. Devl Biol. 121, 526-541.

Nishida, H. ANd Satoh, N. (1983). Cell lineage analysis in ascidian embryos by intracellular injection of a tracer enzyme. I. Up to the eight-cell stage. Devl Biol. 99, 382-394.

Nishida, H. ANd Satoh, N. (1985). Cell lineage analysis in ascidian embryos by intracellular injection of a tracer enzyme. II. The 16and 32-cell stages. Devl Biol. 110, 440-454

NishidA, H. AND SATOH, N. (1989). Determination and regulation in the pigment cell lineage of the ascidian embryo. Devl Biol. 132, 355-367

Nishikata, T., Mita-Mryazawa, I., Deno, T. and Satoh, N. (1987a). Muscle cell differentiation in ascidian embryos analysed with a tissue specific monoclonal antibody. Development 99 , 163-171.

Nishikata, T., Mrta-Miyazawa, I., Deno, T., Takamura, K. and SATOH, N. (1987b). Expression of epidermis-specific antigens during embryogenesis of the ascidian, Halocynthia roretzi. Dev/ Biol. 121, 408-416.

Nishikata, T., Mrta-Mryazawa, I. and Satoh, N. (1988). Differentiation expression in blastomeres of cleavage-arrested embryos of the ascidian Halocynthia roretzi. Develop. Growth and Differ. 30, 371-381.

Norman, C., Runswick, M., Pollock, R. and Treisman, R. (1988). Isolation and properties of cDNA clones encoding SRF, a transcription factor that binds to the c-fos serum response element. Cell 55, 989-1003.

Nússlein-Volhard, C., Frohnhofer, H. G. and Lehmann, R. (1987). Determination of anteroposterior polarity in Drosophila. Science 238, 1675-1681.

Ortolani, G. (1987). The developmental capacity of the animal blastomeres of the 8-cell ascidian embryo. Acta Embryol. Morph. exp. 8, 353-360.

Padgett, R. W., St. Johnston, R. D. and Gelbart, W. M. (1987). A transcript from a Drosophila pattern gene predicts a protein homologous to the transforming growth factor- $\beta$ family. Nature, Lond. 325, 81-84.

Pinney, D. F., Pearson-White, S. H., Konieczny, S. F., Latham, K. E. And Emerson Jr, C. P. (1988). Myogenic lineage determination and differentiation: Evidence for a regulatory gene pathway. Cell 53, 781-793

Priess, J. R., Schnabel, H. and Schnabel, R. (1987). The glp-1 locus and cellular interactions in early $C$. elegans embryos. Cell $51,601-611$

Priess, J. R. AND Thomson, J. N. (1987). Cellular interactions in early C. elegans embryos. Cell 48, 241-250.

Rebagliat1, M. (1989). An RNA recognition motif in the bicoid protein. Cell 58, 231-232.

Reverberi, G., Ortolani, G. and Ferruzza, N. F. (1960). The causal formation of the brain in the ascidian larva. Acta Embryol. Morph. exp. 3, 296-336.

Rosa, F. M. (1989). Mix.1, a homeobox mRNA inducible by mesoderm inducers, is expressed mostly in the presumptive endodermal cells of Xenopus embryos. Cell 57, 965-974. 
Rossant, J. (1985). Interspecific cell markers and cell lineage in mammals. Philos. Trans. R. Soc. London Ser. B. 312, 3-19.

Ruiz i Altaba and Melton, D. A. (1989a). Interaction between peptide growth factors and homeobox genes in the establishment of antero-posterior polarity in frog embryos. Nature, Lond. 341, 33-38.

Ruiz I Altaba and Melton, D. A. (1989b). Involvement of the Xenopus homeobox gene Xhox 3 in pattern formation along the anterior-posterior axis. Cell 57, 317-326.

Rushlow, C. A., Han, K., Manley, J. L. And Levine, M, (1989). The graded distribution of the dorsal morphogen involves selective nuclear transport in Drosophila. Cell 59, 1165-1177.

Sargent, T. D., Jamrich, M. AND Dawid, I. B. (1986). Cell interactions and the control of gene activity during erly development of Xenopus laevis. Devl Biol. 114, 238-246.

Sassone-Corsi, P., Visvader, J., Ferland, L., Mellon, P. L. and VERMA, I. M. (1988). Induction of proto-oncogene fos transcription through the adenylate cyclase pathway: characterization of a cAMP-responsive element. Genes \& Dev. 2, 1529-1538.

SАтон, N. (1979). On the 'clock' mechanism determining the time of tissue-specific enzyme development during ascidian embryogenesis. I. Acetylcholinesterase development in cleavagearrested embryos. J. Embryol. exp. Morph. 54, 131-139.

Scharf, S. R. AND Gerhart, J. C. (1983). Axis determination in eggs of Xenopus laevis: A critical period before first cleavage, identified by the common effects of cold, pressure and ultraviolet irradiation. Devl Biol. 99, 75-87.

SChneuwly, S., Klemenz, R. ANd Gehring, W. J. (1987). Redesigning the body plan of Drosophila by ectopic expression of the homeotic gene Antennapedia. Nature, Lond. 325 816-818.

SCOTT, M. P. AND Carroll, S. B. (1987). The segmentation and homeotic gene network in early Drosophila development. Cell 51, 689-698.

Sen, R. and Baltimore, D. (1986). Multiple nuclear factors interact with the immunoglobulin enhancer sequences. Cell 46, 705-716.

Slack, J. M. W., Darlington, B. G., Heath, J. K. and Godsave, S. F. (1987). Mesoderm induction in early Xenopus embryos by heparin-binding growth factors. Nature, Lond. 326, 197-200.

Slack, J. M. W., Isaacs, H. V. and Darlington, B. G. (1988). Inductive effects of fibroblast growth factor and lithium ion on Xenopus blastula ectoderm. Development 103, 581-590.

SMrTH, J. C. (1987). A mesoderm-inducing factor is produced by a Xenopus cell line. Development 99, 3-14.

Sмгтн, J. C. (1989). Mesoderm induction and mesoderm-inducing factors in early amphibian development. Development 105 , $665-677$.

Smith, J. C. AND SLACK, J. M. W. (1983). Dorsalization and neural induction: Properties of the organizer in Xenopus laevis. J. Embryol. exp. Morph. 78, 299-317.

Snape, A., Wylie, C. C., Smith, J. C. and Heasman, J. (1987). Changes in states of commitment of single animal pole blastomeres of Xenopus laevis. Devl Biol. 119, 503-510.

Sprenger, F., Stevens, L. M. ANd NÚsslein-Volhard, C. (1989) The Drosophila gene torso encodes a putative receptor tyrosine kinase. Nature, Lond. 338, 478-483.

St. Johnston, R. D. And Gelbart, W. M. (1987). Decapentaplegic transcripts are localized along the dorsal-ventral axis of the Drosophila embryo. EMBO J. 6, 2785-2791.

STROME, S. (1989). Generation of cell diversity during early embryogenesis in the nematode Caenorhabditis elegans. Int. Rev. Cytol. 114, 81-123.

Strome, S. AND WoOd, W. B. (1982). Immunofluorescence visualization of germ line-specific cytoplasmic granules in embryos, larvae, and adults of Caenorhabditis elegans. Proc. natn. Acad. Sci. U.S.A. 79, 1558-1562.

Struhl, G., Struhl, K. and Macdonald, P. M. (1989). The gradient morphogen bicoid is a concentration-dependent transcriptional activator. Cell 57, 1259-1273.

Sulston, J. E., Schierenderg, E., White, J. G. And Thomson, J. N. (1983). The embryonic cell lineage of the nematode Caenorhabditis elegans. Devl Biol. 100, 64-119.
Takahashi, K. And Yoshil, M. (1981). Development of sodium, calcium and potassium channels in the cleavage-arrested embryo of an ascidian. J. Physiol. 315, 515-529.

Tapscott, S. J., Davis, R. L., Thayer, M. J., Cheng, P.-F., Weintraub, H. and Lasser, A. B. (1988). MyoD1: A nuclear phosphoprotein requiring a Myc homology region to convert fibroblasts to myoblasts. Science 242, 405-411.

Technau, G. M., Becker, T. and Campos-Ortega, J. A. (1988). Reversible commitment of neural and epidermal progenitor cells during embryogenesis of Drosophila melanogaster. Wilhelm Roux' Arch. devl Biol. 197, 413-418.

Technau, G. M. and Campos-Ortega, J. A. (1986). Lineage analysis of transplanted individual cells in embryos of Drosophila melanogaster. II. Commitment and proliferative capabilities of neural and epidermal cell progenitors. Wilhelm Rour' Arch. devl Biol. 195, 445-454.

Thaller, C. and Eichele, G. (1987). Identification and spatial distribution of retinoids in the developing chick limb bud. Nature, Lond. 327, 625-628.

Van Den Biggelaar, J. A. M. and Guerrier, P. (1979). Dorsoventral polarity and mesentoblast determination as concomitant results of cellular interactions in the mollusc Patella vulgata. Devl Biol. 68, 462-471.

VINCENT, J.-P. AND GERHART, J. C. (1987). Subcortical rotation in Xenopus eggs: An early step in embryonic axis specification. Devl Biol. 123, 526-539.

Wang, G. V. L., Dolecki, G. J., Carlos, R. and Humphreys, T (1990). Characterization and expression of two sea urchin homeobox gene sequences. Dev. Genet. (in press).

Weeks, D. L. ANd Melton, D. A. (1987). A maternal mRNA localized to the vegetal hemisphere in Xenopus eggs codes for a growth factor related to TGF- $\beta$. Cell 51, 861-867.

Weintraud, H., Tapscott, S. J., Davis, R. L., Thayer, M. J., Adam, M. A., Lassar, A. B. ANd Miller, A. D. (1989). Activation of muscle-specific genes in pigment, nerve, fat, liver, and fibroblast cell lines by forced expression of MyoD. Proc. natn. Acad. Sci. U.S.A. 86, 5434-5438.

WetTs, R. AND Fraser, S. E. (1989). Slow intermixing of cells during Xenopus embryogenesis contributes to the consistency of the blastomere fate map. Development 105, 9-15.

Wharton, K. A., Johansen, K. M., Xu, T. and ArtavanisTSAKONAS, S. (1985). Nucleotide sequence from the neurogenic locus notch implies a gene product that shares homology with proteins containıng EGF-like repeats. Cell 43, 567-581.

WhITTAKER, J. R. (1973). Segregation during ascidian embryogenesis of egg cytoplasmic information for tissue-specific enzyme development. Proc. natn. Acad. Sci. U.S.A. 70 2096-2100.

WhITTAKER, J. R. (1977). Segregation during cleavage of a factor determining endodermal alkaline phosphatase development in ascidian embryos. J. exp. Zool. 202, 139-154.

WhITTAKER, J. R. (1979). Cytoplasmic determinants of tissue differentiation in the ascidian egg. In Determinants of Spatial Organization (ed. S. Subtelny and I. R. Konigsberg), pp. 29-51. New York: Academic Press.

WhrTtAKER, J. R. (1980). Acetylcholinesterase development in extra cells caused by changing the distribution of myoplasm in ascidian embryos. J. Embryol. exp. Morph. 55, 343-354.

WhITTAKER, J. R. (1982). Muscle lineage cytoplasm can change the developmental expression in epidermal lineage cells of ascidian embryos. Devl Biol. 93, 463-470.

WHITTAKER, J. R. (1983). Quantitative regulation of acetylcholinesterase development in the muscle lineage cells of cleavage-arrested ascidian embryos. J. Embryol. exp. Morph. 76, 235-250.

Whittaker, J. R., Ortolani, G. and Farinella-Ferruzza, N (1977). Autonomy of acetylcholinesterase differentiation in muscle lineage cells of ascidian embryos. Devl Biol. 55, 196-200.

WILSON, E. B. (1896). The Cell in Development and Inheritance. New York: Macmillan.

WILson, E. B. (1925). The Cell in Development and Heredity, Third Edition. New York: Macmillan. 
Wright, W. E., SASSOON, D. A. AND Lin, V. K. (1989). Myogenin, a factor regulating myogenesis, has a domain homologous to MyoD. Cell 56, 607-617.

Wylie, C. C., Snape, A., Heasman, J. and Smith, J. C. (1987). Vegetal pole cells and commitment to form endoderm in Xenopus laevis. Devl Biol. 119, 496-502.

Yochem, J. AND GreENwald, I. (1989). glp-1 and lin-12, genes implicated in distinct cell-cell interactions in C. elegans, encode similar transmembrane proteins. Cell 58, 553-563.

ZaLOKAR, M. AND SARDET, C. (1984). Tracing of cell lineage in embryonic development of Phallusia mammillata (ascidia) by vital staining of mitochondria. Devl Biol. 102, 195-205.

(Accepted 22 December 1989) 